\title{
Research
}

\section{Future changes in the supply of goods and services from natural ecosystems: prospects for the European north}

\author{
Roland Jansson $^{1}{ }^{1}$ Christer Nilsson ${ }^{1}$, E. Carina H. Keskitalo ${ }^{2}$, Tatiana Vlasova $^{3}$, Marja-Liisa Sutinen $^{4}$, Jon Moen $^{1}, \underline{\text { F. Stuart Chapin }}$

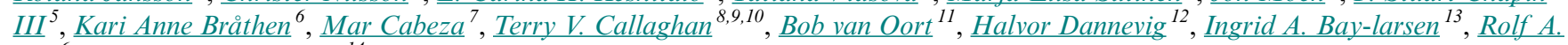 \\ $\underline{\operatorname{Ims}}^{6}$ and Paul Eric Aspholm ${ }^{14}$
}

\begin{abstract}
Humans depend on services provided by ecosystems, and how services are affected by climate change is increasingly studied. Few studies, however, address changes likely to affect services from seminatural ecosystems. We analyzed ecosystem goods and services in natural and seminatural systems, specifically how they are expected to change as a result of projected climate change during the 21st century. We selected terrestrial and freshwater systems in northernmost Europe, where climate is anticipated to change more than the global average, and identified likely changes in ecosystem services and their societal consequences. We did this by assembling experts from ecology, social science, and cultural geography in workshops, and we also performed a literature review. Results show that most ecosystem services are affected by multiple factors, often acting in opposite directions. Out of 14 services considered, 8 are expected to increase or remain relatively unchanged in supply, and 6 are expected to decrease. Although we do not predict collapse or disappearance of any of the investigated services, the effects of climate change in conjunction with potential economical and societal changes may exceed the adaptive capacity of societies. This may result in societal reorganization and changes in ways that ecosystems are used. Significant uncertainties and knowledge gaps in the forecast make specific conclusions about societal responses to safeguard human well-being questionable. Adapting to changes in ecosystem services will therefore require consideration of uncertainties and complexities in both social and ecological responses. The scenarios presented here provide a framework for future studies exploring such issues.
\end{abstract}

Key Words: Barents Region; biodiversity; climate change; ecosystem services; forestry; game species; outdoor recreation; reindeer husbandry; social-ecological systems

\section{INTRODUCTION}

Northern areas of the globe and in particular the Arctic have warmed about twice as fast as the global average over the last century (ACIA 2005, IPCC 2013), and models indicate continued warming. The changing climate affects ecosystems as well as human livelihood and well-being (ACIA 2005, Hovelsrud and Smit 2010). Ecosystem services, defined as the benefits humans obtain from ecosystems (MA 2005a) and use for their well-being (Fisher et al. 2009), encapsulate human dependence on ecosystems and are likely to change along with climate (Mooney et al. 2009).

The Millennium Ecosystem Assessment (MA 2003) provided a framework for assessing changes in ecosystem services, and a few studies have since evaluated climate-change effects on ecosystem services at regional scales (MA 2005b, Schröter et al. 2005). Most such studies focus on human-dominated ecosystems, such as agricultural and urban areas, analyzing effects on services such as crop production and pollination. Less is known about how services provided by natural or seminatural ecosystems, where most of Earth's biodiversity resides, will be affected by climate change. Most such efforts have focused on carbon balance and sequestration. Given that both communities and large resource production networks such as forestry rely on resources from seminatural ecosystems, such knowledge is important.
Forecasts of ecosystem services are hampered by uncertainty about drivers, unknown responses to climate and ecosystem change, stochasticity and nonlinearities in interactions among species, ecosystem components, and ecosystems, in addition to uncertainty related to climate change itself, and those inherent to modeling and scale of projections. Successful forecasts must identify ecosystem attributes for which uncertainty can be reduced sufficiently to provide information useful in decision making (Clark et al. 2001). Methods to synthesize information and provide predictions relevant to society at regional scales are still largely lacking. Previous attempts have either focused on a diversity of drivers (MA 2005b, Arctic Council 2013), single ecosystem types (Hermy et al. 2008), small areas (Peterson et al. 2003, Ford and Smit 2004), or large-scale quantitative projections necessitating simplifying assumptions (Schröter et al. 2005).

We discuss climate-driven changes in ecosystem services in the Barents Region, which comprises the arctic and subarctic regions of mainland Europe, encompassing the northern parts of Norway, Sweden, and Finland, and northwestern Russia (Fig. 1). The region is already in a period of rapid climate change, and also future warming is expected to be pronounced (Kattsov and Källén 2005, Overland et al. 2011). With over 6 million people, the Barents Region is the most densely populated Arctic Region with clusters of heavy industry and developed infrastructure. Natural-

\footnotetext{
${ }^{1}$ Department of Ecology and Environmental Science, Umeå University, ${ }^{2}$ Department of Geography and Economic History, Umeå University, ${ }^{3}$ Institute of Geography, Russian Academy of Sciences, ${ }^{4}$ Finnish Forest Research Institute, Rovaniemi Research Unit, ${ }^{5}$ Institute of Arctic Biology, University of Alaska, Fairbanks, ${ }^{6}$ Department of Arctic and Marine Biology, UiT- The Arctic University of Norway, ${ }^{7}$ Department of Biosciences, University of Helsinki, ${ }^{8}$ Royal Swedish Academy of Sciences, Stockholm, Sweden, ${ }^{9}$ Department of Animal and Plant Sciences, University of Sheffield, UK, ${ }^{10}$ Department of Botany, Tomsk State University, Russia, ${ }^{11}$ CICERO - Center for International Climate and Environmental Research, Oslo, ${ }^{12}$ Western Norway Research Institute, ${ }^{13}$ Nordland Research Institute, ${ }^{14}$ Bioforsk, Svanhovd
} 
resource sectors such as forestry, mining, and oil and gas extraction are important to national as well as local and regional economies (Glomsrød et al. 2009). Local use of ecosystems includes hunting, fishing, and berry and mushroom picking, which are important to the economy, subsistence and recreation of communities in the region. Reindeer husbandry, practiced in most of the region, is important to the regional economy and to the cultural identity of indigenous Sami people.

Fig. 1. Map of the Barents Region (dark gray), consisting of northern Norway, Sweden, Finland, and northwestern Russia. Inset globe shows the position of the Barents Region (encircled) within the Northern Hemisphere.

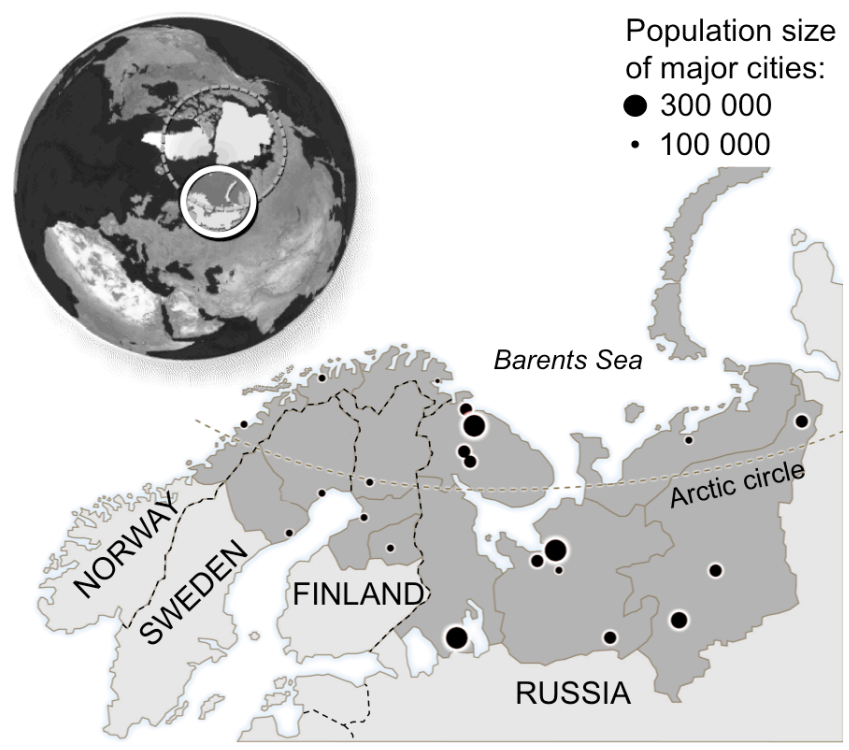

Our aim in this study is to project how climate change during the 21 st century will affect the provision of renewable goods and services offered by natural and seminatural freshwater and terrestrial ecosystems and considered important by local communities in the Barents Region. Based on an expert assessment, we focused on renewable resource-utilizing practices related to wood production, reindeer products, game and fish species, berries and mushrooms, biodiversity, and cultural activities. Services from marine ecosystems, and areas where the surface has been completely transformed by human action, such as agricultural and urban systems, were excluded, as were services important only at large scales, such as the role of carbon sequestration for mitigating global climate change.

\section{METHODS}

\section{Climate change}

The Barents Region has experienced higher temperature and precipitation and less snow cover during the last decades, just as other northern parts of the globe (Serreze et al. 2000, ACIA 2005, IPCC 2013). From the various projections and scenarios of climate available, we considered a limited set of projections of change until 2100, to provide bounds to expectations. These models project an annual temperature increase in the Barents Region by $3-10^{\circ} \mathrm{C}$ from the period $1961-1990$ to $2071-2100$, with the greatest warming in the east (Rummukainen et al. 2004, Benestad 2008, Overland et al. 2011). Winters will warm more (Dec-Feb; $4-7^{\circ} \mathrm{C}$ ) than summers (Jun-Aug; $1-4^{\circ} \mathrm{C}$ ). The temperature increase is expected to result in longer growing seasons (30-60 more days with a mean temperature $\left.>5^{\circ} \mathrm{C}\right)$. The number of days with snow cover will decrease by $20-90$ days, with the largest decreases in the southwestern lowland areas and the smallest in the east. The number of freeze-thaw events (zero crossings) during winter is projected to increase in areas with continental climate, going from $0-6$ to 15 in 2071-2100. In northern Sweden, annual runoff will increase by $20-30 \%$ between 1961-1990 and 2071-2100 (Andréasson et al. 2004). Seasonal variation in runoff and streamflow will change as less precipitation falls as snow, leading to higher winter flows and lower spring flood peaks, except for the northernmost Russian rivers where most winter precipitation will still come as snow (Woo et al. 2008).

\section{Ecosystem services}

To forecast changes in ecosystem service provision for the Barents Region, we adopted a strategy whereby experts selected services from natural ecosystems considered to be typical and characteristic to the region, as well as the most important for local communities in the Barents Region. Given this distinction, a focus was placed on renewable resource-utilizing practices. The expert assessments were made by a team of expert ecologists, social scientists, and cultural geographers, who first convened in a workshop and selected ecosystem services. We analyzed changes in provisioning and cultural ecosystem services and their consequences in interdependent ecological and social systems (Fig. 2; MA 2005a). We selected the provisioning services wood products, animal products, berries and mushrooms, along with the cultural services tourism, recreation, and cultural ties to the land. We considered biodiversity, defined as the diversity of species, communities, and ecosystems, as supporting other services (Fig. 2). With higher species richness, species providing specific ecological functions are more likely to be present, and rare species have been found to often support unique functions (Mouillot et al. 2013). In addition, both species additions and losses have societal consequences.

For each ecosystem service identified, cause-effect relationships were constructed, going from climate drivers to societal consequences and possible adaptation strategies, based on expert workshops and literature surveys. At the first workshop, we had experts on climate change effects on ecosystem services, societal consequences, as well as societal adaptation strategies. At the meeting, cause-effect chains were drafted and discussed until consensus was reached. This was followed by literature review, checking the available evidence for the suggested model, which was then modified if needed, so that the final model was supported by empirical evidence and minimizing subjectivity stemming from the opinions of workshop participants. Literature searches were made in ISI-Thompson Web of Science combining keywords describing services with keywords for climate change. Following the workshop and review, a manuscript was drafted, which was circulated for revision, and further revised after two additional workshops, where focus was put on developing projections of societal consequences and adaptation strategies. Also, additional experts were consulted and included in the manuscript writing process. The scenarios resulting from this process are narratives 
Fig. 2. Conceptual model used in the analyses, consisting of an ecological system of natural or seminatural ecosystems providing ecosystem goods and services to human actors, made possible by the biodiversity at the level of species and ecosystems, and a social system, represented by determinants of human well-being and societal adaptive capacity, affecting the vulnerability or resilience of human actors. The determinants of adaptive capacity are relevant at a hierarchy of scales nested within each other, going from global to local communities and individual households. Human actors manage ecosystems by harvest, control measures and conservation strategies (solid arrows), having side-effects on adaptive capacity (dashed arrows), and develop or affect societal adaptive capacity by various activities and decisions, having side-effects on ecosystems. Adapted from Millennium Ecosystem Assessment (2003), Chapin et al. (2006), and Eakin and Lemos (2006).

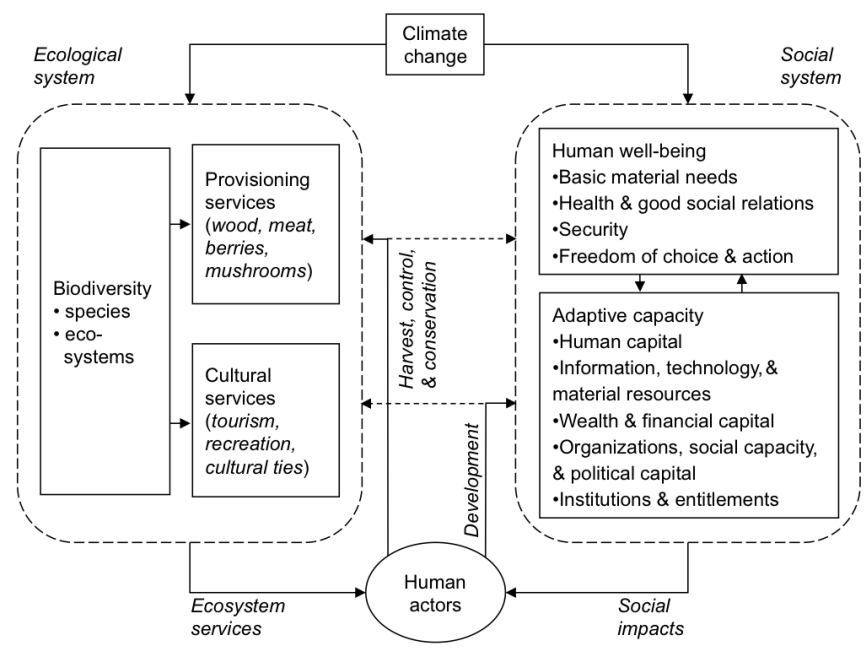

and hypothesized cause-and-effect relationships (Greeuw et al. 2000). An example flow chart displaying the cause-and-effect relationship from one ecosystem service, wood production, is displayed in Figure 3. The societal consequences of climate change include both effects on human well-being and effects on the society's adaptive capacity. Adaptive capacity can be defined as actors' or communities' management of current and past stresses, their ability to anticipate and plan for future change, and resilience to perturbations (Plummer and Armitage 2010). Although a focus is placed on how changes impact the natural environment, we do not a priori distinguish between the two social subsystems, human well-being and adaptive capacity, but rather emphasize the intersection between the ecological and social systems in the selected literature.

\section{RESULTS}

Of the 14 ecosystem services analyzed, we project decreases until 2100 in the provision of six services, and increases or no change in the remaining eight services (Table 1). We do not predict collapse or a dramatic increase in any service, although drawing conclusions about the magnitude of change was generally difficult. For most services, the direct or immediate responses are expected to be different from the indirect or delayed ones, making linear temporal trajectories of change unlikely. Ignorance of the strength of species interactions and the unpredictability of extreme events are the greatest cause for uncertainty in the predictions. Substantial societal consequences are expected as a result of changes in ecosystem services, calling for strategies for adaptation (Table 2). To put emphasis on the projected chain of events, we have in essence "linearized" processes that in reality consist of feedback loops. These feedbacks are represented by "indirect or delayed effects" in Table 1 and "secondary ecosystem and societal responses" in Figure 3.

Fig. 3. Conceptual model of the cause-and-effect relationships expected as a result of climate change for one ecosystem service, wood production (shaded box). Solid arrows indicate positive, enhancing effects, whereas dashed arrows indicate negative effects

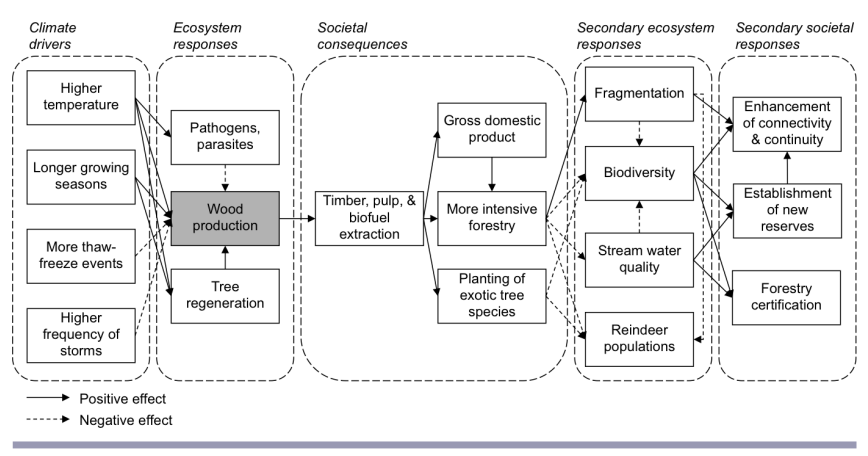

\section{Changes in provisioning services and projected impacts}

\section{Wood production}

Warmer and longer growing seasons will stimulate tree growth, facilitate regeneration, and increase the forest area (Fig. 3, Table 1; Wolf et al. 2008a). These responses are expected to increase productivity in managed forests (Kellomäki et al. 2008) and expand forestry to new areas (Koca et al. 2006, Devi et al. 2008). Opposing effects could counteract these beneficial effects of warming (Fig. 3). For example, warmer weather may increase forest pests such as pathogens, diseases, invasive herbivorous insects, and plants (Niemelä et al. 2001, Wolf et al. 2008b, Valtonen et al. 2011). In northern Fennoscandia, northward expanding geometrid moth outbreaks have caused massive devastation of subarctic birch forests (Jepsen et al. 2011), most likely owing to warmer winters and springs (Jepsen et al. 2008, 2011). Climate change is also expected to lead to more severe winter storms and icing events (Chapin et al. 2007). Freeze-thaw events, which kill growing plant tissues (meristems) and cause irregular tree growth, are also expected to increase in frequency (Lindner et al. 2010). In areas with more continental climate, such as Russia, higher temperatures could cause summer drought and more fires. Lindner et al. (2010) also suggest that climate change will reduce access to forest land outside the frost period because of wet soil. Finally, tree species composition may change as deciduous tree species expand northward (Lindner et al. 2010), although tree species composition in managed forests are mostly determined by planting and seeding. 
Table 1. Projected effects of climate change on ecosystem services of importance to local communities provided by natural or seminatural ecosystems in the Barents Region expected during the 21st century. Expected net trend is the direction of change in the ecosystem service parameter (increase or decrease).

\begin{tabular}{|c|c|c|c|c|c|c|}
\hline \multirow[t]{2}{*}{ Ecosystem service } & \multicolumn{2}{|c|}{ Effects of climate change } & \multirow{2}{*}{$\begin{array}{l}\text { Geographic } \\
\text { location }\end{array}$} & \multirow[t]{2}{*}{ Causes for uncertainty } & \multirow{2}{*}{$\begin{array}{l}\text { Expected } \\
\text { net trend }\end{array}$} & \multirow[t]{2}{*}{ Certainty } \\
\hline & Direct or immediate & Indirect or delayed & & & & \\
\hline \multicolumn{7}{|l|}{ Provisioning services } \\
\hline Wood production & $\begin{array}{l}\text { Faster growth, higher } \\
\text { productivity, more } \\
\text { storm and disease } \\
\text { damage }\end{array}$ & Forests in new areas & $\begin{array}{l}\text { Throughout forested areas; } \\
\text { largest where new forests } \\
\text { may establish }\end{array}$ & $\begin{array}{l}\text { Strengths of species } \\
\text { interactions, pest and } \\
\text { disturbance regime }\end{array}$ & Increase & Likely \\
\hline \multicolumn{7}{|l|}{ Meat production } \\
\hline Moose & $\begin{array}{l}\text { Higher survival and } \\
\text { more reproduction }\end{array}$ & $\begin{array}{l}\text { Increase in predator } \\
\text { pressure, expansion into } \\
\text { new areas }\end{array}$ & $\begin{array}{l}\text { Northern areas and high } \\
\text { altitudes }\end{array}$ & $\begin{array}{l}\text { Density-dependent } \\
\text { population effects, } \\
\text { harvest regulations }\end{array}$ & Increase & Uncertain \\
\hline Ptarmigan & $\begin{array}{l}\text { Higher survival and } \\
\text { reproduction }\end{array}$ & Habitat loss & High altitudes & $\begin{array}{l}\text { Mechanisms for } \\
\text { population dynamics } \\
\text { poorly known }\end{array}$ & Decrease & Uncertain \\
\hline Salmonid fishes & $\begin{array}{l}\text { Mixed: higher survival } \\
\text { and reproduction in } \\
\text { some species, } \\
\text { temperature stress in } \\
\text { others }\end{array}$ & $\begin{array}{l}\text { Habitat loss in cold- } \\
\text { adapted species, } \\
\text { competition from warm- } \\
\text { adapted species }\end{array}$ & $\begin{array}{l}\text { Transition zone between } \\
\text { alpine and forest zones }\end{array}$ & $\begin{array}{l}\text { Strengths of species } \\
\text { interactions }\end{array}$ & No change & Uncertain \\
\hline Edible berries & $\begin{array}{l}\text { Higher production due } \\
\text { to more pollination } \\
\text { and earlier fruit } \\
\text { development }\end{array}$ & $\begin{array}{l}\text { Increases in forest and } \\
\text { shrub cover reducing light } \\
\text { availability }\end{array}$ & $\begin{array}{l}\text { Throughout, biggest losses } \\
\text { in alpine heaths replaced by } \\
\text { tall shrubs or trees }\end{array}$ & $\begin{array}{l}\text { Mechanisms of fruit set, } \\
\text { strength of species } \\
\text { interactions }\end{array}$ & No change & Uncertain \\
\hline Mushrooms & Later fruiting & Habitat changes & $\begin{array}{l}\text { Follows pattern of delayed } \\
\text { end of growing season }\end{array}$ & $\begin{array}{l}\text { Mechanisms for fruit } \\
\text { set, species interactions }\end{array}$ & No change & Uncertain \\
\hline Reindeer products & $\begin{array}{l}\text { Mixed: lower winter } \\
\text { survival and increased } \\
\text { summer food } \\
\text { availability, more } \\
\text { insect harassment }\end{array}$ & Possible range contraction & $\begin{array}{l}\text { Winter survival: western } \\
\text { part, insect harassment: } \\
\text { where summer snow is lost }\end{array}$ & $\begin{array}{l}\text { Relative importance of } \\
\text { summer and winter } \\
\text { conditions, competing } \\
\text { land-uses }\end{array}$ & Decrease & Uncertain \\
\hline \multicolumn{7}{|l|}{ Cultural services } \\
\hline $\begin{array}{l}\text { Summer outdoor } \\
\text { recreation }\end{array}$ & Longer seasons & $\begin{array}{l}\text { Habitat and landscape } \\
\text { changes }\end{array}$ & Throughout & Tourism behavior & Increase & Likely \\
\hline $\begin{array}{l}\text { Winter outdoor } \\
\text { recreation }\end{array}$ & $\begin{array}{l}\text { Increased pressure as } \\
\text { snow conditions in } \\
\text { resorts further south } \\
\text { deteriorate }\end{array}$ & $\begin{array}{l}\text { Shorter seasons and more } \\
\text { unpredictable conditions } \\
\text { for winter sports }\end{array}$ & Throughout & Tourism behavior & Decrease & Likely \\
\hline $\begin{array}{l}\text { Cultural ties to the } \\
\text { land }\end{array}$ & $\begin{array}{l}\text { Decrease in culturally } \\
\text { important species }\end{array}$ & $\begin{array}{l}\text { Landscape } \\
\text { transformation of } \\
\text { culturally important areas }\end{array}$ & Throughout & Cultural evolution & Decrease & Uncertain \\
\hline \multicolumn{7}{|l|}{ Biodiversity } \\
\hline Species richness & $\begin{array}{l}\text { Colonization by } \\
\text { mobile species }\end{array}$ & $\begin{array}{l}\text { Species losses, } \\
\text { colonization of less } \\
\text { mobile species }\end{array}$ & $\begin{array}{l}\text { Local richness throughout; } \\
\text { species new to the region } \\
\text { primarily in the south; } \\
\text { losses primarily in the } \\
\text { north and mountains }\end{array}$ & $\begin{array}{l}\text { Barriers to migration, } \\
\text { land-use changes, } \\
\text { species interactions, } \\
\text { episodic and extreme } \\
\text { events }\end{array}$ & Increase & Very likely \\
\hline $\begin{array}{l}\text { Proportion of } \\
\text { native to exotic } \\
\text { species }\end{array}$ & $\begin{array}{l}\text { Increase in population } \\
\text { growth rates and } \\
\text { reproduction of } \\
\text { exotics }\end{array}$ & $\begin{array}{l}\text { More habitat and areas } \\
\text { becomes suitable for } \\
\text { invasion }\end{array}$ & $\begin{array}{l}\text { Areas with highest } \\
\text { population density and } \\
\text { infrastructure }\end{array}$ & $\begin{array}{l}\text { Species interactions, } \\
\text { disturbance frequency } \\
\text { and extent }\end{array}$ & Decrease & Likely \\
\hline $\begin{array}{l}\text { Number of species } \\
\text { unique to northern } \\
\text { areas }\end{array}$ & $\begin{array}{l}\text { Mixed: enhanced } \\
\text { reproduction in some } \\
\text { species, reduced in } \\
\text { others }\end{array}$ & $\begin{array}{l}\text { Habitat loss, invasion of } \\
\text { competing species }\end{array}$ & High-altitude areas & $\begin{array}{l}\text { Strengths of species } \\
\text { interactions, adaptation } \\
\text { potential, level of } \\
\text { conservation effort }\end{array}$ & Decrease & Likely \\
\hline $\begin{array}{l}\text { Diversity of } \\
\text { ecosystem types }\end{array}$ & $\begin{array}{l}\text { Loss of some cold- } \\
\text { adapted ecosystems }\end{array}$ & $\begin{array}{l}\text { New ecosystem types } \\
\text { from new species and } \\
\text { climatic conditions }\end{array}$ & $\begin{array}{l}\text { Losses in permafrost and } \\
\text { high-altitude areas, new } \\
\text { types in southern and } \\
\text { lowland areas }\end{array}$ & $\begin{array}{l}\text { Species-environment } \\
\text { relationships }\end{array}$ & No change & Likely \\
\hline
\end{tabular}


Table 2. Societal consequences of changes in ecosystem service provision caused by climate change in the Barents Region, recommended strategies to adapt to changes, and obstacles to adaptation.

\begin{tabular}{lll}
\hline \hline Ecosystem service & Societal consequences & Strategies for adaptation \\
\hline $\begin{array}{l}\text { Provisioning services } \\
\text { Wood production }\end{array}$ & $\begin{array}{l}\text { More forest harvest and economic } \\
\text { revenue, more intense forestry } \\
\text { practices, more fragmented forests } \\
\text { and loss of biodiversity }\end{array}$ & $\begin{array}{l}\text { Pluralism in forestry management methods, } \\
\text { establishment of new reserves and } \\
\text { enhancement of connectivity, planting of } \\
\text { new species and provenances }\end{array}$
\end{tabular}

Meat production

Moose

Ptarmigan

Salmonid fishes

Edible berries

Mushrooms

Reindeer husbandry

Cultural services

Summer outdoor recreation

Winter outdoor

recreation

Cultural ties to the land

Biodiversity

Species richness

Exotic species

Number of species

unique to northern areas

Ecosystem types
Hunting in new areas, postponement of hunting season

Loss of hunting opportunities

Decreased importance of some fisheries, loss in economic revenue

Increased potential for berry picking and sales in the short term

Potential contraction of mushroom picking season

Economic losses, loss of enterprises, land-use rights potentially called into question

Longer seasons, potentially more visitors

Shorter seasons, potentially less visitors, although visitors to winter sport areas may choose the Barents Region over southern areas with less reliable snow conditions

Loss of connection with the land, loss of traditional knowledge from sport fishing
Altered harvest regulations, including timing of the hunting season

Development of sustainable harvest models

Restoration of migratory pathways, spawning and rearing habitats, no introduction of competitors beyond natural barriers

None necessary

Promotion of use of wider range of species

Development of legal rights, stimulation of alternative source of revenue from reindeer husbandry
Inadequate legislation, lack of population data

Inadequate legislation, insufficient natural history knowledge, lack of training

Conflicting land uses, inadequate legislation, insufficient natural history

knowledge

Conflicts between commercial berry picking companies and landowners

Lack of training, insufficient natural history knowledge

Unclear legal land-use rights, socioeconomic development of society

Enhancement of tourism infrastructure, targeting a different, foreign public

Diversification of ecotourism activities, exploitation of exotism

Conflicting land uses, conservation management, language barriers Lack of economic resources and training

Education, training, increased awareness of threatened values, effort to document vanishing knowledge

Lack of knowledge, economic resources and training

Enhancement of native species migration by Inadequate legislation, lack of removal of barriers, establishment of new economic resources Species not protected by reserves new species

reserves or extension of existing ones, stimulation of innovation and entrepreneurship to exploit new goods Restrictions on species introductions,

Lower supply of some traditional goods and services, loss in traditional recreational and cultural values, potentially new goods and services Loss of products, and cultural and educational values screening for potential problem species, monitoring, pest control

Captive breeding or cultivation, new reserves, better poaching control, education

Loss in traditional recreational and cultural values, potentially new types of recreation
Education, stimulation of innovation, enhancement of infrastructure for recreation
Inadequate legislation, free trade treaties, insufficient natural history knowledge, lack of economic resources

Inadequate legislation, insufficient natural history knowledge, lack of economic resources and training Lack of economic resources and training

\section{Impact on forestry}

A higher wood production will increase profits from wood and paper products (Solberg et al. 2003, Trømborg et al. 2008). It may also result in intensified forest management with shorter rotations, more fertilizers, use of more southern provenances, and new tree species (Table 2), leading to increased forest fragmentation (Kellomäki et al. 2008) and local species losses. Shorter periods of ground frost may require new techniques to avoid or repair damage from heavy machinery. The risks for forestry associated with climate change may be reduced by promoting pluralism in forest management, so that each forestry action, e.g., fertilization, planting of new species, is implemented where best suited. However, these adaptive strategies might conflict with biodiversity conservation goals and require adjustments in legislation and training (Table 2). More intense forestry may be balanced by enhancing actions to conserve 
species, such as managing for increased abundance of dead wood and leaving buffer strips along ecological boundaries (Table 2). The regional effects of increased forestry profits are uncertain for at least two major reasons: (1) It is uncertain how regulations and institutions will influence the regional retention of profits. Transnational corporations may reap most of them, resulting in minimal stimulation of the regional or local economy. (2) Many effects of globalization, including changes in demand for wood products, expanded plantation forestry in developing nations, and import/export regulations, all influence the economic benefits of increased wood harvest. Improved access to the Northern Sea Route in response to melting sea ice may lead to new seaports (Ragner 2008), providing access for timber harvest in new areas of remaining old-growth forest in Russia (Yaroshenko et al. 2001).

\section{Meat and fish production}

Moose (Alces alces), ptarmigan (Lagopus spp.), and salmonid fishes play significant cultural and economic roles in rural communities in the Barents Region. Climate factors regulate growth-rate variation in moose, probably through impacts on predator success and foraging (Vucetich and Peterson 2004), with warming being expected to lead to higher survival and reproduction of moose (Table 1). Milder winters with less snow should speed up population growth rates, although density regulation may buffer population increases (Post and Stenseth 1998). Long-term expansion of Salix shrub and forest communities to the north and toward higher elevations is likely to allow geographical expansion of moose similar to that during earlier warming periods of the Quarternary (Schmölcke and Zachos 2005). Species distribution modeling predicts future range expansion of moose (Hof et al. 2012), and observations indicate recent population increases (Hörnberg 2001).

Willow Ptarmigan (Lagopus lagopus) and to some extent Rock Ptarmigan (L. mutus) are economically valuable game species in alpine and subalpine parts of the Barents Region. Ptarmigans may respond positively to warmer starts of growing seasons (Watson et al. 1998), but predator-prey dynamics make outcomes uncertain, and they may ultimately lose habitat as tundra is replaced by forest. Their populations vary cyclically, often synchronously with other species over large areas (Watson et al. 2000), indicating climate control that may interact with predatorprey dynamics. Population cycles of Willow Ptarmigan follow those of voles and lemmings through predation (Moss and Watson 2001), but it is unclear how the fading of vole and lemming fluctuations over large areas may affect ptarmigan dynamics. Cycles of Willow Ptarmigan and rodents are no longer synchronous (Henden et al. 2011), and recent population dynamics appear more irregular with less frequent good years and long troughs with low numbers (Holmstad et al. 2005). Willow Ptarmigan density is indirectly controlled by reindeer through their grazing on Salix shrubs (Ims et al. 2007, den Herder et al. 2008, Henden et al. 2011). Shrub expansion on the tundra, if not browsed by reindeer (den Herder et al. 2008), may temporarily favor Willow Ptarmigan (Ehrich et al. 2012) until the tundra eventually becomes closed forest.

Salmonids are extensively fished in the Barents Region. Economically important species are Atlantic salmon (Salmo salar), brown trout (Salmo trutta), Arctic charr (Salvelinus alpinus), European grayling (Thymallus thymallus), and whitefish
(Coregonus spp.). The abundance and growth of most salmonids are climatically limited, suggesting that warming climate may result in faster growth and higher fish returns in many populations, but may also result in temperature stress. Habitat use varies with species, life-history stage, and migration behavior, and intraspecific differentiation and local adaptations complicate the picture (Reist et al. 2006). Thus, even within the same species, responses to climate change may vary. Many populations are expected to experience more frequent warm spells that reduce survival of eggs and juvenile fish (Reist et al. 2006) and restrict habitats for cold-water fish such as Atlantic salmon, Arctic charr, and whitefish. Framstad et al. (2006) add that ice cover on rivers protects young salmon during winter, and a reduction of ice cover may thus be expected to be negative. Temperature variation during winter may also increase the formation of frazil ice and anchor ice that can kill juveniles during winter (Weber et al. 2013).

Increased interspecific competition and changing parasite loads may also play a role. For example, Arctic charr have disappeared from subarctic lakes following invasion by pike (Esox lucius), presumably as a result of recent warming (Byström et al. 2007). Arctic charr and whitefish will probably disappear from the south of the Barents Region (Wrona et al. 2005), whereas range expansions to the north are limited by the lack of landmasses (Reist et al. 2006). Arctic charr is predicted to lose $73 \%$ of its range in Sweden by 2100 because of increased temperatures and projected pike invasions (Hein et al. 2012). In the Russian north, local residents have observed expansion in the distribution of perch (Perca fluviatilis), replacing salmonid fishes (Vlassova 2006). Climate change is also expected to change fish migration patterns. Higher productivity in freshwater ecosystems following increased temperature may reduce charr migration from freshwater to marine habitats after spawning (Wrona et al. 2005). This will probably reduce yields because charr grow faster in the productive marine environments. Thus, responses to climate change should vary among populations in all salmonids in the Barents Region, making it difficult to make regional generalizations.

\section{Production of edible berries and mushrooms}

Berries and mushrooms are harvested commercially across the entire region, but are also important for subsistence in rural areas such as northwest Russia (Keskitalo and Kulyasova 2009). Berry production may be stimulated by warmer climate, but habitat loss and species interactions may result in decline, making predictions uncertain (Table 1). Production of berries varies among years, and depends on the weather in the preceding years (Selås 2000, Krebs et al. 2009). Also, some of the berry-producing dwarf shrubs are particularly sensitive to warm events in winter (Bokhorst et al. 2009) but recovery from damage is common (Aerts 2010). The complex response of berry production to climate reflects the multiple steps of climate influence, such as flowering response to spring frosts and temperature, pollination to temperature and precipitation, and berry formation and growth in response to moisture and heat. Changing snow cover may also promote pathogen attacks, reducing growth of berry-producing plants (Olofsson et al. 2011). Increased extents of insect outbreaks in oligotrophic birch forest zones induce understory vegetation state shifts from dominance of berry-producing shrubs to grasses (Karlsen et al. 2013). In contrast, dampened lemming cycles resulting from warmer winters are likely to favor increased 
biomass of berry-producing shrubs (Olofsson et al. 2012). Thus, any projections of future berry production are speculative.

Predictions for mushroom production are also uncertain (Table 1). Mushroom production is highly variable but tends to increase in wet years. Cues for mushroom fruiting are poorly known, but a warmer climate might lead to earlier resource acquisition necessary for fruiting, whereas cues for fruiting might occur over a longer period. Gange et al. (2007) reported extended fruiting periods for a set of species in the UK, starting earlier and ending later. In contrast, Kauserud et al. (2008) documented fruiting dates of mushrooms being delayed by on average 13 days since 1980 in Norway, with longer delays in earlier-fruiting (> 30 days) than later-fruiting species, making the net response to climate change uncertain.

\section{Effects on hunting/fishing/gathering}

The predicted climate changes should affect the provision of meat, berries, and mushrooms by modifying harvest rates and species composition (Table 1). These changes may be accommodated by using existing harvest methods but may also require new methods (Table 2). With changing harvest methods, local communities, and often the entire society, run the risk of losing local and traditional knowledge, which is already threatened by depopulation (Heleniak 1999) and globalization. On the other hand, large environmental and climatic changes may make certain types of knowledge less relevant. However, the introduction of new harvest techniques may also provide an opportunity to exploit new knowledge and foster adaptive and sustainable resource use. The options to mitigate effects of changing climate on production of salmonids may be taken as an example. One potential action used previously to counter population reductions caused by fragmentation by dams is introduction of fish, for example salmon from hatcheries. Spread of parasites (Heggberget et al. 1993) and mixing of escapees with wild populations, leading to genetic deterioration of wild populations (Hindar et al. 2006) make this alternative unsustainable. In rivers where recreational fishing is important, bag and size limits could be further constrained, and catch and release fishing, although not ideal (Wilkie et al. 1996), could be made mandatory. However, another option is to restore degraded salmonid habitats by removing artificial migration barriers, restore spawning beds, or improve winter low-flow refuges to reduce mortality (Battin et al. 2007). Changes in the timing of reproduction associated with climate change may be met by altering harvest regulations, including timing. Changes in the geographic distribution of productivity of for example ptarmigan and salmonids call for development of sustainable harvest models, to avoid over-harvest in areas and time periods of low productivity (Table 2). Such strategies may encounter obstacles in the form of inadequate legislation and cause land-use conflicts.

\section{Reindeer populations}

Reindeer provide subsistence for husbandry in most of the Barents Region. In many areas, grazing by primarily sheep may be important, potentially competing with reindeer. Reindeer population sizes are largely regulated by winter food availability (Tveraa et al. 2007, Moen 2008), whereas meat production is largely related to reindeer density on summer pastures (Bråthen et al. 2007). Effects of climate change on reindeer populations are uncertain, but may be mostly negative in the long run (Table 1).
Shorter winters reduce the risk of starvation and mortality. Winter forage is however expected to become more limited because of ice-crust formation following frequent zero transitions (Hansen et al. 2013, Stien et al. 2012), and because of lichens, the preferred winter food of reindeers, being outcompeted (Moen 2008, Rees et al. 2008). The net outcome is uncertain and may vary regionally, for example between oceanic and continental areas (Tveraa et al. 2007). In addition, harassment by insects is expected to increase, reducing fecundity and growth rate of calves (Moen 2008). At the same time, higher plant productivity and longer growing seasons will make more food available to reindeer during summer, although management of reindeer population density may also affect plant productivity (Bråthen et al. 2007) and forage composition (Ravolainen et al. 2011). In the long run, the observed (Callaghan et al. 2013) and expected (Wolf et al. $2008 a$ ) expansion of trees and shrubs into alpine areas may reduce grazing areas (Rees et al. 2008), although reindeer may themselves curb this process (Bråthen et al. 2007, den Herder et al. 2008, Ravolainen et al. 2014). In the most extreme scenarios of climate change, most of the Barents Region will be warmer than the present climate envelope for reindeer.

Impact on reindeer husbandry

Scenarios for the future of reindeer husbandry are mixed (Rees et al. 2008). Reindeer husbandry already operates under marginal economic conditions. In addition, its flexibility has been compromised by habitat loss and changes in governance (Tyler et al. 2007, Hausner et al. 2011). Options for reorganization include geographic range contractions, stationary herding, or even farming. Range contraction may result in traditional grazing rights being questioned if herds are no longer present (Table 2).

Longer growing seasons would advance migration to and increase the residence time in summer grazing areas. Moving herds by foot may become more difficult because of unreliable ice and snow conditions, which are of special concern in Russia, where reindeer herds are closely monitored by herders (Rees et al. 2008). Such problems may foster modified herding techniques with less transportation and increased use of supplemental forage during winter. Adaptive capacity of reindeer husbandry for a crosscompliance of conservation and development is however dependent on well-functioning governance (Ulvevadet and Hausner 2011). Accordingly, Brännlund and Axelsson (2011) found that nonclimatic factors, such as border closures, forestry, and reindeer herding laws pose a greater threat to future reindeer herding than climate, at least in the short term. Thus, management changes may compensate for a climate-related decline in reindeer husbandry (Table 2). From an ecological point of view, an important strategy to enhance the adaptive capacities of reindeer husbandry is to increase or maintain a choice of grazing sites (Moen 2008). This capacity is already limited as a result of forestry, leading to up to $50 \%$ losses of winter grazing in the Nordic countries (Sandström et al. 2006, Horstkotte et al. 2011). Reservoirs, roads, and petroleum industries also constrain grazing areas (Rees et al. 2008), and increasing infrastructural expansion and ecosystem degradation may further impact reindeer husbandry (Forbes et al. 2011).

\section{Changes in cultural services and projected impacts}

Some cultural services are closely connected to the abovementioned products that people obtain from ecosystems, whereas 
others relate to the experience or aesthetics of nature. We consider tourism, recreation, and cultural ties to the land.

\section{Changing conditions for, and responses from, tourism and recreation}

Because choice of destination and activity are highly seasonal, we distinguish between summer and winter recreation. Climate conditions for summer tourism are projected to improve in the Barents Region (Perch-Nielsen et al. 2010), whereas winter tourism may decline (Table 1). Simulations developed by Hamilton et al. (2005) and Lindner et al. (2010) predict that a warmer climate would both increase the number of tourists travelling to the Barents Region countries in the summer and make people in the region choose destinations closer to home. Summer outdoor recreation will benefit from an increased number of warm days balanced by an increase in the number of days with rainfall, although occasional rain is tolerated by visitors to the area (Førland et al. 2013). The effect of climate change on winter recreation will depend on trends in snow- and ice-related recreation. Shorter duration of snow cover, thinner snowpack, more wet and icy snow, more thaw periods, and more frequent rain and storm events will make conditions less predictable and favorable for skiing and other activities requiring snow or ice. The fate of commercial outdoor recreation activities depends on tourist behavior, the majority being visitors from outside the region. The Barents Region will be the only European region with a long snow season except for mountainous areas. Moen and Fredman (2007) suggest that shorter winters and lower exposure to winter-like conditions in most of Europe would reduce interest in snow- and ice-related recreation, reducing numbers of winter visitors. Alternatively, snow and ice could be exploited as exotic attractions. Changes in opportunities for tourism and recreation can be met by diversifying the type of activities offered and by targeting a different, foreign public (Table 2).

\section{Ties to the land}

Ecosystems contribute to human well-being by providing culturally important species and scenic landscapes (MA 2005a), and ecosystem changes may result in loss of cultural ties to the land (Table 1). Ties to the land are partly manifested through harvesting of products provided by ecosystems, allowing local, including indigenous, peoples to continue traditional land-use patterns. Such ties to the land may be affected by changes in geographic distribution of species in response to climate change, as well as by ongoing urbanization and globalization. Because of climate change, important species may be displaced geographically or disappear, and landscapes as they are featured in cultural traditions may no longer exist. Examples of such landscape changes are forestation of alpine and tundra areas and loss or significant reduction in duration of winters with continuous cover of snow and ice. The aesthetic and cultural values of the Barents Region, with some of the last relatively intact ecosystems in Europe, are important to local residents and the broader European community both as a motivation to spend time on the land and for their contribution to the existence value of the land. However, these values are likely to differ among stakeholder groups. For many local residents, any ecological change, such as changes in species composition and diversity, or landscape structure, such as location of treeline, may reduce their ties to the landscape (e.g., Forbes et al. 2011), thus potentially increasing its vulnerability to other social and economic changes.
When environmental cues traditionally used by residents no longer work, the predictive ability of residents is reduced, making traditional knowledge less relevant and ultimately reducing selfconfidence in local use. These challenges can be met to some extent by research, education, and training (although we have low predictive power for some of the changes), and by increasing the awareness of how previous challenges have been met by innovative as well as traditional adaptation measures (Table 2).

\section{Biodiversity}

Range shifts, exotic and range-restricted species

Longer, warmer summers and shorter, milder winters will favor invasion of southern species to the Barents Region provided they can reach the region (Henningsson and Alerstam 2005, Huntley et al. 2008, Hof et al. 2012), whereas cold-adapted species may experience contracting geographic ranges because there are no appropriate areas to move to (Hof et al. 2012; Table 1). Given that the distribution of many species is limited by temperature (Normand et al. 2009), and that species richness generally decreases with latitude, more species may be gained than lost (Table 1), assuming that species can track their preferred climate and expand their distributions (Sætersdal et al. 1998, Bakkenes et al. 2002, Hof et al. 2012). Northern Europe is dominated by natural and seminatural vegetation, implying that anthropogenic barriers are less constraining than in many regions further south (Sætersdal et al. 1998). However, many species in Europe have not filled their potential climatic ranges (Svenning and Skov 2004, Araújo and Pearson 2005), suggesting that they were unable to respond to past climatic shifts and may not fully exploit this expanded climate envelope. Also, long-term observations show contrasting responses even in the same plant species during recent past warming, because of variation in barriers to dispersal and species interactions (Pellissier et al. 2010, le Roux et al. 2014) and because climate warming affects many aspects of plant growth, reproduction, and survival (Callaghan et al. 2013). Thus, many species cannot be expected to track future climate change (Svenning and Sandel 2013).

Although past shifts in climate have been as rapid as the ones expected for the 21st century (Overpeck et al. 2005), dispersal rates vary among species, with good dispersers, such as winged insects, responding rapidly (Coope and Wilkins 1994), whereas trees require centuries or longer to attain equilibrium with climate (Bennett et al. 1986, Svenning and Sandel 2013). Easily dispersed and common species are most likely to move in synchrony with climate (Alsos et al. 2012), because production of many propagules with good dispersal ability allows rapid colonization of areas that become climatically suitable. The Barents Region harbors rather few exotic species (Dynesius et al. 2004), the majority of which have invaded from warmer areas. A warmer climate will pave the way for an expansion of these species (Sykes 2001) and an invasion of new ones that are already adapted to warmer conditions (Hof et al. 2012). Thus, although species numbers are expected to increase, the new species are likely to be widespread ones with good dispersal ability or species introduced by humans. Local species richness may increase throughout the region but may be highly variable depending on propagule arrival rates and the resistance to invasion by local ecosystems.

The species most likely to go extinct or decline substantially are specialists such as those dependent on snow and ice (Callaghan 
et al. 2005) and those with small population sizes in shrinking northern and high altitude habitats, such as high-Arctic plant species (Thuiller et al. 2005) and alpine snow bed habitats (Björk and Molau 2007). Most of those species are circumpolar and are only locally threatened, although many of them have subspecies or local varieties endemic to the Barents Region. Some threatened species may be of central importance for the ecosystem, and if these disappear others will likely follow. Such a chain of events has been implicated in the fading of distinct population cycles of voles and lemmings from many areas (Ims and Fuglei 2005). This is potentially the result of a shorter snow period, thinner snow cover, and more freeze-thaw events leading to ice crusts and reduced food availability (Callaghan et al. 2005, Hansen et al. 2013). As a result, predator populations dependent on voles and lemmings have decreased (Hörnfeldt et al. 2005, Hellstedt et al. 2006, Schmidt et al. 2012).

\section{Community and ecosystem changes}

The Barents Region has condensed climatic gradients with shorter distances between temperate, boreal, and tundra biomes than anywhere in the Arctic, suggesting that local ecosystems may be displaced in a large portion of the region (Callaghan et al. 2004), with some cold-adapted ecosystems disappearing, and new ones appearing (Table 1). Species generally respond individually to climate change, implying that present communities will disappear and new ones will form. Some ecosystem types associated with cold climate are likely to disappear. For example, lowland permafrost areas, such as palsa mires, are predicted to melt, and their communities will be lost although individual species may persist (Luoto et al. 2004). Indeed, observations have recorded loss of permafrost mires in northern Sweden in the past 30 years (Åkerman and Johansson 2008)

The greatest expected change in terrestrial habitat is replacement of alpine and tundra areas by forests and shrublands (Moen et al. 2004, Wolf et al. 2008a), although the extent of forest expansion may be constrained by soil conditions (Sutinen et al. 2005) and ecosystem processes, such as grazing (Wookey et al. 2009). In the southernmost parts of the Barents Region, colonization by new species may lead to development of new types of communities and ecosystems. The southwestern parts are expected to become climatically suitable for deciduous hardwood species such as Quercus robur and Tilia cordata (Koca et al. 2006), although they are unlikely to establish before 2100 because of lags in species responses to climate change (Svenning and Sandel 2013). The total area of tundra is anticipated to remain stable in the region as losses to expanding forests are compensated by northward expansions of tundra into polar desert habitats (Wolf et al. 2008a).

\section{Societal impact from biodiversity change}

Changes in species distributions may have profound consequences for conservation management (Table 2) and governments' ability to fulfill international environmental conventions. Protected areas may no longer adequately conserve the flora and fauna of the region, as species move out of, or invade reserves (Araújo et al. 2011, Kujala et al. 2011), calling for evaluation of forecasted biodiversity changes in protected areas together with more proactive (adaptive) planning (Araújo et al. 2004, Pressey et al. 2007). Biodiversity protection traditionally controls introduction and spread of invasive species to avoid extinctions of native ones.
The challenge will be to enhance the spread of native or accepted species, and to control the spread of unwanted, exotic species that are potential pests (Chapin et al. 2007). Successful conservation strategies need to facilitate species migration so that native species are allowed to adjust their distributions to match new climatic conditions, for example by minimizing the distance between reserves and fostering land use that favors dispersal between reserves and biodiversity hotspots (Araújo et al. 2011, Kujala et al. 2011). This may be done, for example, by managing natural corridors such as streams and rivers to remove barriers and increase their continuity (Williams et al. 2005). For some species, assisted migration (McLachlan et al. 2007), a highly debated alternative (Ricciardi and Simberloff 2009), or captive breeding/ cultivation may be necessary. All these actions need proper risk assessments and require accommodation by legal frameworks. Spread of new species implies new potential services, whereas the (local) disappearance of native species means that social adjustments to the loss of certain services may be needed. Stimulation of innovation and entrepreneurship to exploit such new services may be needed.

\section{Interactions among ecosystem services}

So far, we have mostly ignored potential interactions among ecosystem services to facilitate identifying the direct cause-andeffect relationships of climate change associated with each ecosystem service considered. In reality, such interactions are, however, numerous and important. In Figure 4, we have indicated the most significant ones. Changes in all provisioning services except for wood production are expected to influence summer outdoor recreation (summer taken to be equivalent of the entire bare-ground season), because harvest of these resources may change. Likewise, we envision that changes in biodiversity-related services affect cultural ties to the land, as would changes in forestry and reindeer herding practices. Changes in forestry associated with changes in wood production might also affect the abundance of moose, ptarmigan, edible berries, and conditions for reindeer grazing. In addition, planting of new tree species may result in new ecosystem types and facilitate invasions. In contrast, larger moose populations might negatively affect wood production because of sapling herbivory. Making projections for ecosystem services being influenced by many other services, such as summer outdoor recreation, is more difficult than for those lacking such interactions. If interactions among the societal consequences and adaptation strategies are considered, the situation becomes even more complex.

\section{DISCUSSION AND CONCLUSION}

This expert assessment and literature review of major ecosystem services relevant to the Barents Region project changes in many of the ecosystem services derived from natural ecosystems in the region. Although substantial changes in many ecosystem services were projected, the literature drawn upon here does not predict collapse or disappearance of any service (Table 1). It might be that the present literature does not take into account the impact of the more extreme climate change scenarios (IPCC 2013), which imply that the climate in most of the Barents Region by 2100 will be much warmer and wetter than what is able to maintain Arctic and subecosystems (Ims et al. 2013). Indeed, the exact nature and magnitude of the changes in ecosystem services are difficult to assess, given the limited predictive power for many services. This 
uncertainty partly reflects the dependence of many services on multiple factors, often working in opposite directions (Schmitz et al. 2003) and that we lack empirical analogues in the case of combinations of novel climates and ecosystems (Ims et al. 2013). This problem is greatest for services influenced by changes in other services (Figure 4). Large-scale social, economic, and political changes will influence the extent of climate change as well as the impact on different resource use interests under varying market conditions and population-change scenarios. The ability to forecast climate effects on ecosystem functioning also depends on approaches that include links and feedbacks between biotic components of the ecosystem (Schmitz et al. 2003). Given that the net outcome may often be determined by the strength of species interactions, which vary spatially, quantitative predictions are often likely to be specific for a certain place and time. Also, because empirical studies addressing such spatial variation are few (Bråthen et al. 2007, Callahan et al. 2013), generalizations for a large and variable region such as the Barents are inherently difficult to make. However, given that we constructed chains of cause-and-effect relationships for each ecosystem service, these can serve as hypotheses, for example, for predictive modeling in situations when quantitative projections are feasible and necessary, and for guiding adaptive monitoring systems for observing and acting upon future changes (Lindenmayer and Likens 2009).

Fig. 4. Potential interactions among the ecosystem services studied. Arrows indicate that change in one ecosystem service is expected to have repercussions on or lead to changes in another service. In cases where the interactions go both ways, the arrows are double-headed. Only the interlinkages judged to be most relevant are depicted by arrows.

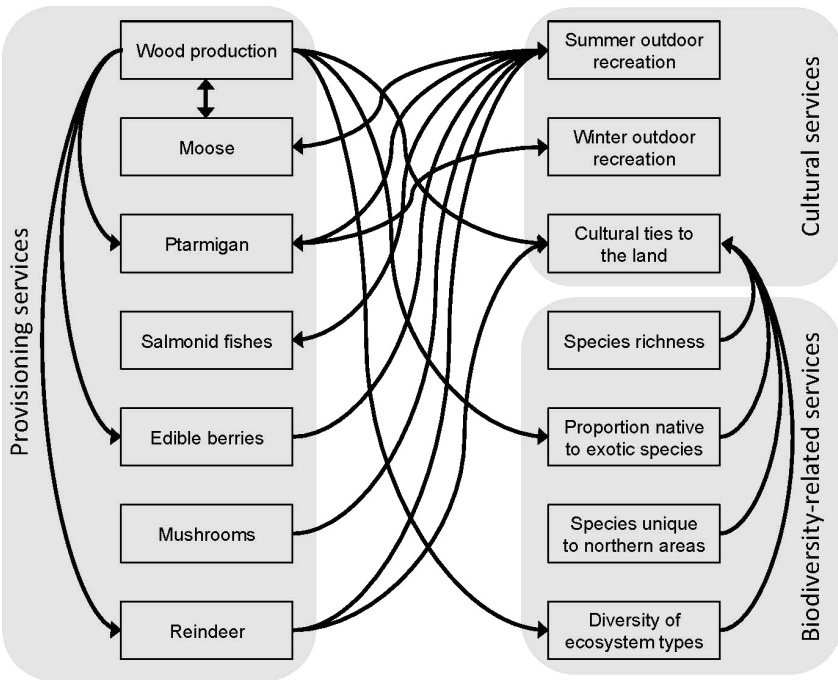

Alternatives for adapting societies to changes in service provision were identified for each ecosystem service (Table 2), although many obstacles to successful adaptation were foreseen, such as inadequate legislation, land-use conflicts, and mutually incompatible management actions to improve ecosystem services (Table 2). Even if such obstacles are overcome, there might be limits to adaptation if the changes in ecosystem services alter cultural practices and lead to loss of places important to communities (Adger et al. 2009). However, this study views change in the targeted region only, and does not take into account changes in market or resource use conditions that may impact population or ecosystems as a result of, for instance, change in other regions or in global product supply chains. In addition, there are many interdependencies and potential linkages among adaptation strategies to changes in different ecosystem services, but exploring these in greater depth was beyond the scope of the paper, because it necessitates modeling of these interactions. Major reorganization of human use of ecosystems may occur as a result of the combined effects of climate change and globalization (O'Brien and Leichenko 2000). Even in the absence of climate change, changes in social-ecological systems during the 21 st century may be large. All the studied ecosystem services have either experienced large changes in their provision or how they have been utilized by humans during the 20th century. Forestry and reindeer husbandry have undergone rationalization and mechanization (Sandström et al. 2006), fundamentally changing for example working conditions (Hjelm 1991). The game species analyzed have changed in population size, as has the hunting legislation. For example, moose have gone from being very rare to abundant, with moose hunting becoming culturally and economically important in rural areas (Hörnberg 2001). Furthermore, mushrooms only started to be utilized widely for food after the Second World War in Sweden, and berry picking has shifted from being a source of extra income for local communities to being organized by labor hire companies with labor from, for example, Thailand (Sténs and Sandström 2013). Likewise, tourism and recreation has grown to become a major part of both local and global economies. Taken together, these changes demonstrate both substantial adaptive capacity of local communities, as well as the large role of reorganization and internationalization of production in resource use.

Societies and sectors will vary in their adaptive capacity. Reindeer husbandry as a largely traditional indigenous practice is not only dependent on local provision of ecosystem services but is also impacted by all other resource use in the areas, as it constitutes a very small sector with few practitioners and little economic national importance in comparison with, for instance, the large role of forestry. Given this situation, socioeconomic, political, and climate change impacts will necessarily need to be assessed together (Keskitalo 2008, Rees at al. 2008, Ulvevadet and Hausner 2011). Moreover, socially-oriented observations (SOO) based on local people's perceptions and statistics, help to identify the main issues and targets for life quality, human capital, and environmental improvement, thus setting targets for further monitoring. SOO in the Russian European North show that human-induced disturbances, such as uncontrolled forests cuttings and poaching, are increasing while observed changes in climate and biota have become additional factors influencing land use and overall sustainability (Vlasova and Volkov 2013).

The predicted changes in ecosystem services are likely to occur gradually, although rapidly emerging surprises with associated state changes are almost inevitable (Lindenmayer et al. 2010). Species distributions and vegetation composition are unlikely to be in equilibrium with climate at the end of the 21 st century (Svenning and Sandel 2013). Although this means that some of the changes likely to occur in response to climate change during 
the 21 st century will not be realized until later, it also means that nonstationarity is to be expected (Milly et al. 2008), and that continuous change needs to be taken into account in resource management. In addition, surprisingly slow ecosystem changes or lack of expected changes (Callaghan et al. 2013) also need to be better understood. Apart from the risks, a warmer climate may further provide new opportunities and possibilities for society, for example in making resources more accessible and resulting in potentially higher general productivity (although large-scale extreme events may be an obstacle). Taking advantage of the opportunities that may arise will require investments, knowledge, and material resources that are readily available to only a few actors, such as transnational corporations, and may thus impact the distribution of resource use rights in practice (cf. Keskitalo 2008). The policy decisions taken to mitigate and adapt to climate change or to respond to other long-term changes could substantially modify the direct responses of ecosystem services to climate. Building capacity for different and diverging communities to cope with, or adapt to, changes in ecosystem services, including beyond the local or regional level, and especially under relatively quick economic change and urbanization, is a crucial issue for future studies.

Responses to this article can be read online at: http://www.ecologyandsociety.org/issues/responses. $\mathrm{php} / 7607$

\section{Acknowledgments:}

This study was funded by the Nordic Council of Ministers, and the Research Council of Norway (NORKLIMA).

\section{LITERATURE CITED}

Adger, W. N., S. Dessai, M. Goulden, M. Hulme, I. Lorenzoni, D. R. Nelson, L. O. Naess, J. Wolf, and A. Wreford. 2009. Are there social limits to adaptation to climate change? Climatic Change 93:335-354. http://dx.doi.org/10.1007/s10584-008-9520$\underline{\mathrm{Z}}$

Aerts, R. 2010. Nitrogen-dependent recovery of subarctic tundra vegetation after simulation of extreme winter warming damage to Empetrum hermaphroditum. Global Change Biology 16:1071-1081. http://dx.doi.org/10.1111/j.1365-2486.2009.01999. $\underline{\mathrm{X}}$

Åkerman, H. J., and M. Johansson. 2008. Thawing permafrost and thicker active layers in sub-arctic Sweden. Permafrost and Periglacial Processes 19:279-292. http://dx.doi.org/10.1002/ ppp.626

Alsos, I. G., D. Ehrich, W. Thuiller, P. B. Eidesen, A. Tribsch, P. Schönswetter, C. Lagaye, P. Taberlet, and C. Brochmann. 2012. Genetic consequences of climate change for northern plants. Proceedings of the Royal Society B - Biological Sciences 279:2042-2051. http://dx.doi.org/10.1098/rspb.2011.2363

Andréasson, J., S. Bergström, B. Carlsson, L. P. Graham, and G. Lindström. 2004. Hydrological change — climate change impact simulations for Sweden. Ambio 33:228-234. http://dx.doi. org/10.1579/0044-7447-33.4.228

Araújo, M. B., D. Alagador, M. Cabeza, D. Nogués-Bravo, and W. Thuiller. 2011. Climate change threatens European conservation areas. Ecology Letters 14:484-492. http://dx.doi. org/10.1111/j.1461-0248.2011.01610.x

Araújo, M. B., M. Cabeza, W. Thuiller, L. Hannah, and P. H. Williams. 2004. Would climate change drive species out of reserves? An assessment of existing reserve-selection methods. Global Change Biology 10:1618-1626. http://dx.doi.org/10.1111/ j.1365-2486.2004.00828.X

Araújo, M. B., and R. G. Pearson. 2005. Equilibrium of species' distributions with climate. Ecography 28:693-695. http://dx.doi. org/10.1111/j.2005.0906-7590.04253.x

Arctic Climate Impact Assessment (ACIA). 2005. Arctic climate impact assessment: scientific report. Cambridge University Press, Cambridge, UK.

Arctic Council. 2013. Arctic resilience interim report 2013. Stockholm Environment Institute and Stockholm Resilience Centre, Stockholm, Sweden.

Bakkenes, M., J. R. M. Alkemade, F. Ihle, R. Leemans, and J. B. Latour. 2002. Assessing effects of forecasted climate change on the diversity and distribution of European higher plants for 2050. Global Change Biology 8:390-407. http://dx.doi.org/10.1046/ j.1354-1013.2001.00467.x

Battin, J., M. W. Wiley, M. H. Ruckelshaus, R. N. Palmer, E. Korb, K. K. Bartz, and H. Imaki. 2007. Projected impacts of climate change on salmon habitat restoration. Proceedings of the National Academy of Sciences 104:6720-6725. http://dx.doi.org/10.1073/ pnas.0701685104

Benestad, R. E. 2008. Empirical-statistical downscaling of Russian and Norwegian temperature series. Met.no Report 13/2008. Norwegian Meteorological Institute, Oslo, Norway. [online] URL: http://met.no/Forskning/Publikasjoner/metno_report/2008/ filestore/metno 13-2008.pdf

Bennett, K. D., J. H. Lawton, A. Gibbs, M. H. Williamson, M. W. Holdgate, W. D. Hamilton, and G. R. Conway. 1986. The rate of spread and population increase of forest trees during the postglacial. Philosophical Transactions of the Royal Society of London B 314:523-531. http://dx.doi.org/10.1098/rstb.1986.0071

Björk, R. G., and U. Molau. 2007. Ecology of alpine snowbeds and the impact of global change. Arctic, Antarctic and Alpine Research 39:34-43. http://dx.doi.org/10.1657/1523-0430(2007)39 [34: eoasat]2.0.co;2

Bokhorst, S. F., J. W. Bjerke, H. Tømmervik, T. V. Callaghan, and G. K. Phoenix. 2009 Winter warming events damage sub-Arctic vegetation: consistent evidence from an experimental manipulation and a natural event. Journal of Ecology 97:1408-1415. http://dx.doi.org/10.1111/j.1365-2745.2009.01554. $\underline{\mathrm{X}}$

Brännlund, I., and P. Axelsson. 2011. Reindeer management during the colonization of Sami lands: a long-term perspective of vulnerability and adaptation strategies. Global Environmental Change 21:1095-1105. http://dx.doi.org/10.1016/j.gloenvcha.2011.03.005 
Bråthen, K. A., R. A. Ims, N. G. Yoccoz, P. Fauchald, T. Tveraa, and V. H. Hausner. 2007. Induced shift in ecosystem productivity? Extensive scale effects of abundant large herbivores. Ecosystems 10:773-789. http://dx.doi.org/10.1007/s10021-007-9058-3

Byström, P., J. Karlsson, P. Nilsson, T. van Kooten, J. Ask, and F. Olofsson. 2007. Substitution of top predators: effects of pike invasion in a subarctic lake. Freshwater Biology 52:1271-1280. http://dx.doi.org/10.1111/j.1365-2427.2007.01763.x

Callaghan, T., L. Björn, T. Chapin, Y. Chernov, T. Christensen, B. Huntley, R. Ims, M. Johansson, D. Riedlinger, S. Jonasson, N. Matveyeva, W. Oechel, N. Panikov, and G. Shaver. 2005. Arctic tundra and polar desert ecosystems. Pages 243-352 in Arctic Climate Impact Assessment (ACIA). Arctic climate impact assessment: scientific report. Cambridge University Press, Cambridge, UK.

Callaghan, T. V., L. O. Björn, Y. Chernov, T. Chapin, T. R. Christensen, B. Huntley, R. A. Ims, M. Johansson, D. Jolly, S. Jonasson, N. Matveyeva, N. Panikov, W. Oechel, G. Shaver, S. Schaphoff, S. Sitch, and C. Zöckler. 2004. Synthesis of effects in four Arctic subregions. Ambio 33:469-473. http://dx.doi. org/10.1579/0044-7447-33.7.469

Callaghan, T. V., C. Jonasson, T. Thierfelder, Z. Yang, H. Hedenås, M. Johansson, U. Molau, R. Van Bogaert, A. Michelsen, J. Olofsson, D. Gwynn-Jones, S. Bokhorst, G. Phoenix, J. W. Bjerke, H. Tømmervik, T. R. Christensen, E. Hanna, E. K. Koller, and V. L. Sloan. 2013. Ecosystem change and stability over multiple decades in the Swedish subarctic: complex processes and multiple drivers. Philosophical Transactions of the Royal Society Series B - Biological Sciences 368:1624. http://dx.doi.org/10.1098/rstb.2012.0488

Chapin, F. S., III, K. Danell, T. Elmqvist, C. Folke, and N. Fresco. 2007. Managing climate change impacts to enhance the resilience and sustainability of Fennoscandian forests. Ambio 36:528-533. http://dx.doi.org/10.1579/0044-7447(2007)36[528:MCCITE]2.0.CO:2

Chapin, F. S., III, A. L. Lovecraft, E. S. Zavaleta, J. Nelson, M. D. Robards, G. P. Kofinas, S. F. Trainor, G. D. Peterson, H. P. Huntington, and R. L. Naylor. 2006. Policy strategies to address sustainability of Alaskan boreal forests in response to a directionally changing climate. Proceedings of the National Academy of Sciences 103:16637-16643. http://dx.doi.org/10.1073/ pnas.0606955103

Clark, J. S., S. R. Carpenter, M. Barber, S. Collins, A. Dobson, J. A. Foley, D. M. Lodge, M. Pascual, R. Pielke Jr, W. Pizer, C. Pringle, W. V. Reid, K. A. Rose, O. Sala, W. H. Schlesinger, D. H. Wall, and D. Wear. 2001. Ecological forecasts: an emerging imperative. Science 293:657-660. http://dx.doi.org/10.1126/ science.293.5530.657

Coope, G. R., and A. S. Wilkins. 1994. The response of insect faunas to glacial-interglacial climatic fluctuations. Philosophical Transactions of the Royal Society of London B 344:19-26. http:// dx.doi.org/10.1098/rstb.1994.0046

den Herder, M., R. Virtanen, and H. Roininen. 2008. Reindeer herbivory reduces willow growth and grouse forage in a foresttundra ecotone. Basic and Applied Ecology 9:324-331. http://dx. doi.org/10.1016/j.baae.2007.03.005
Devi, N., F. Hagedorn, P. Moiseev, H. Bugmann, S. Shiyatov, V. Mazepa, and A. Rigling. 2008. Expanding forests and changing growth forms of Siberian larch at the Polar Urals treeline during the 20th century. Global Change Biology 14:581-1591. http://dx. doi.org/10.1111/j.1365-2486.2008.01583.X

Dynesius, M., R. Jansson, M. E. Johansson, and C. Nilsson. 2004. Intercontinental similarities in riparian-plant diversity and sensitivity to river regulation. Ecological Applications 14:173-191. http://dx.doi.org/10.1890/02-5127

Eakin, H., and M. C. Lemos. 2006. Adaptation and the state: Latin America and the challenge of capacity-building under globalization. Global Environmental Change 16:7-18. http://dx. doi.org/10.1016/j.gloenvcha.2005.10.004

Ehrich, D. J.-H. Henden, R. A. Ims, L. O. Doronina, S. T. Killengreen, N. Lecomte, I. Pokrovsky, G. Skogstad, A. A. Sokolov, V. A. Sokolov, and N. Yoccoz. 2012. The importance of willow thickets for ptarmigan and hares in shrub tundra: the more the better? Oecologia 168:141-151. http://dx.doi.org/10.1007/ $\underline{\mathrm{s} 00442-011-2059-0}$

Fisher, B., R. K. Turner, and P. Morling. 2009. Defining and classifying ecosystem services for decision making. Ecological Economics 68:643-653. http://dx.doi.org/10.1016/j.ecolecon.2008.09.014

Forbes, B. C., F. Stammler, T. Kumpulac, N. Meschtyb, A. Pajunen, and E. Kaarlejärvi. 2011. High resilience in the YamalNenets social-ecological system, West Siberian Arctic, Russia. Proceedings of the National Academy of Sciences 106:22041-22048. http://dx.doi.org/10.1073/pnas.0908286106

Førland, E. J., J. K. S. Jacobsen, J. M. Denstadli, M. Lohmann, I. Hanssen-Bauer, H. O. Hygen, and H. Tømmervik. 2013. Cool weather tourism under global warming: comparing Arctic summer tourists' weather preferences with regional climate statistics and projections. Tourism Management 36:567-579. http://dx.doi.org/10.1016/j.tourman.2012.09.002

Ford, J. D., and B. Smit. 2004. A framework for assessing the vulnerability of communities in the Canadian Arctic to risks associated with climate change. Arctic 57:389-400. http://dx.doi. org/10.14430/arctic516

Framstad, E., I. Hanssen-Bauer, A. Hofgaard, M. Kvamme, P. Ottesen, R. Toresen, R. Wright, R. Ådlandsvik, B. Løbersli, and L. Dalen. 2006. Effekter av klimaendringer på økosystem og biologisk mangfold. Direktoratet for naturforvaltning, DNutredning 2-2006, Trondheim, Norway.

Gange, A. C., E. G. Gange, T. H. Sparks, and L. Boddy. 2007. Rapid and recent changes in fungal fruiting patterns. Science 316:71. http://dx.doi.org/10.1126/science.1137489

Glomsrød, S., I. Mäenpää, L. Lindholt, H. McDonald, and S. Goldsmith. 2009. Arctic economies within the Arctic nations. Pages 37-63 in S. Glomsrød and I. Aslaksen. 2009. The economy of the north 2008. Statistics Norway, Oslo, Norway.

Greeuw, S. C. H., M. B. A. van Asselt, J. Grosskurth, C. A. M. H. Storms, N. Rijkens-Klomp, D. S. Rothman, and J. Rotman. 2000. Cloudy crystal balls: an assessment of recent European and global scenario studies and models. Experts' Corner Report, Prospects and Scenarios No 4. European Environment Agency, Copenhagen, Denmark. 
Hamilton, J. M., D. J. Maddison, and R. S. J. Tol . 2005. Effects of climate change on international tourism. Climate Research 29:245-254. http://dx.doi.org/10.3354/cr029245

Hansen, B. B., V. Grøtan, R. Aanes, B. E. Sæther, A. Stien, E. Fuglei, R. A. Ims, N. G. Yoccoz, and A. Ø. Pedersen. 2013. Climate events synchronize the dynamics of a resident vertebrate community in the high-Arctic. Science 339:313-315. http://dx.doi. org/10.1126/science. 1226766

Hausner, V. H., P. Fauchald, T. Tveraa, E. Pedersen, J. Jernsletten, B. Ulvevadet, R. A. Ims, N. Yoccoz, and K. A. Bråthen. 2011. The ghost of development past: the impact of economic security policies on Saami pastoral ecosystems. Ecology and Society 16(3): 4. http://dx.doi.org/10.5751/es-04193-160304

Heggberget, T. G., B. O. Johnsen, K. Hindar, B. Jonsson, L. P. Hansen, N. A. Hvidsten, and A. J. Jensen. 1993. Interactions between wild and cultured Atlantic salmon: a review of the Norwegian experience. Fisheries Research 18:123-146. http://dx. doi.org/10.1016/0165-7836(93)90044-8

Hein, C. L., G. Öhlund, and G. Englund. 2012. Future distribution of Arctic char Salvelinus alpinus in Sweden under climate change: effects of temperature, lake size and species interactions. Ambio 41:303-312. http://dx.doi.org/10.1007/ $\underline{\text { s13280-012-0308-Z }}$

Heleniak, T. 1999. Out-migration and depopulation of the Russian north during the 1990s. Post-Soviet Geography and Economics 40:155-205.

Hellstedt, P., J. Sundell, P. Helle, and H. Henttonen. 2006. Largescale spatial and temporal patterns in population dynamics of the stoat, Mustela erminea, and the least weasel, M. nivalis, in Finland. Oikos 115:286-298. http://dx.doi.org/10.1111/

j.2006.0030-1299.14330.x

Henden, J.-A., R. A. Ims, N. G. Yoccoz, and S. T. Killengreen. 2011. Declining Willow Ptarmigan populations: the role of habitat structure and community dynamics. Basic and Applied Ecology 12:413-422. http://dx.doi.org/10.1016/j.baae.2011.05.006

Henningsson, S. S., and T. Alerstam. 2005. Patterns and determinants of shorebird species richness in the circumpolar Arctic. Journal of Biogeography 32:383-396. http://dx.doi. org/10.1111/j.1365-2699.2004.01204.X

Hermy, M., S. van der Veken, H. Van Calster, and J. Plue. 2008. Forest ecosystem assessment, changes in biodiversity and climate change in a densely populated region (Flanders, Belgium). Plant Biosystems 142:623-629. http://dx.doi.org/10.1080/11263500802411023

Hindar, K., I. A. Fleming, P. McGinnity, and O. Diserud. 2006. Genetic and ecological effects of salmon farming on wild salmon: modelling from experimental results. ICES Journal of Marine Science 63:1234-1247. http://dx.doi.org/10.1016/j.icesjms.2006.04.025

Hjelm, J. 1991. Skogsarbetarna och motorsågen: en studie av arbetsliv och teknisk förändring. Arkiv Förlag, Lund, Sweden.

Hof, A. R., R. Jansson, and C. Nilsson. 2012. Future climate change will favour non-specialist mammals in the (sub)arctics. PLoS ONE 7(12):e52574. http://dx.doi.org/10.1371/journal. pone. 0052574
Holmstad, P. R., P. J. Hudson, V. Vandvik, and A. Skorping. 2005. Can parasites synchronise the population fluctuations of sympatric tetraonids? Examining some minimum conditions. Oikos 109:429-434. http://dx.doi.org/10.1111/j.0030-1299.2005.13702. $\underline{x}$

Hörnberg, S. 2001. Changes in population density of moose (Alces alces) and damage to forests in Sweden. Forest Ecology and Management 149:141-151. http://dx.doi.org/10.1016/S0378-1127 (00)00551-X

Hörnfeldt, B., T. Hipkiss, and U. Eklund. 2005. Fading out of vole and predator cycles? Proceedings of the Royal Society London B 272:2045-2049. http://dx.doi.org/10.1098/rspb.2005.3141

Horstkotte, T., J. Moen, T. Lämås, and T. Helle. 2011. The legacy of logging - estimating arboreal lichen occurrence in a boreal multiple-use landscape on a two century scale. PLOS ONE 6: e28779. http://dx.doi.org/10.1371/journal.pone.0028779

Hovelsrud, G. K., and B. Smit, editors. 2010. Community adaptation and vulnerability in Arctic regions. Springer, Dordrecht, the Netherlands. http://dx.doi.org/10.1007/978-90-481-9174-1

Huntley, B., Y. C. Collingham, S. G. Willis, and R. E. Green. 2008. Potential impacts of climatic change on European breeding birds. PLoS ONE 3:e1439. http://dx.doi.org/10.1371/journal.pone.0001439

Ims, R. A., D. Ehrich, B. C. Forbes, B. Huntley, D. A. Walker, P. A. Wookey, D. Berteaux, U. S. Bhatt, K. A. Bråthen, M. E. Edwards, H. E. Epstein, M. C. Forchhammer, E. Fuglei, G. Gauthier, S. Gilbert, M. Leung, I. E. Menyushina, N. G. Ovsyanikov, E. Post, M. K. Raynolds, D. G. Reid, N. M. Schmidt, A. Stien, O. I. Sumina, and R. Van der Wal. 2013. Terrestrial ecosystems. Pages 385-440 in H. Meltofte, editor. Arctic biodiversity assessment. Status and trends in Arctic biodiversity. Conservation of Arctic Flora and Fauna, Akureyri, Iceland.

Ims, R. A., and E. Fuglei. 2005. Trophic interaction cycles in tundra ecosystems and the impact of climate change. BioScience 55:311-322. http://dx.doi.org/10.1641/0006-3568(2005)055[0311: TICITE]2.0.CO;2

Ims, R. A., N. G. Yoccoz, K. A. Bråthen, P. Fauchald, T. Tveraa, and V. Hausner. 2007. Can reindeer overabundance cause a trophic cascade? Ecosystems 10:607-622. http://dx.doi.org/10.1007/ s10021-007-9060-9

Intergovernmental Panel on Climate Change (IPCC). 2013. Climate change 2013: the physical science basis. Contributions of Working Group 1 to the Fifth Assessment Report of the Intergovernmental Panel on Climate Change. T. F. Stocker, D. Qin, G.-K. Plattner, M. Tignor, S. K. Allen, J. Boschung, A. Nauels, Y. Xia, V. Bex, and P.M. Midgley, editors. Cambridge University Press, Cambridge, UK.

Jepsen, J. U., S. B. Hagen, R. A. Ims, and N. G. Yoccoz. 2008. Climate change and outbreaks of the geometrids Operophtera brumata and Epirrita autumnata in subarctic birch forest: evidence of a recent outbreak range expansion. Journal of Animal Ecology 77:257-264. http://dx.doi.org/10.1111/j.1365-2656.2007.01339.x

Jepsen, J. U., L. Kapari, S. B. Hagen, T. Schott, O. P. L. Vindstad, A. C. Nilssen, and R. A. Ims. 2011. Rapid northwards expansion of a forest insect pest attributed to spring phenology matching 
with sub-Arctic birch. Global Change Biology 17:2071-2083. http://dx.doi.org/10.1111/j.1365-2486.2010.02370.x

Karlsen, S. R., J. U. Jepsen, A. Odland, R. A. Ims, and A. Elvebakk. 2013. Outbreaks by canopy feeding geometrid moth cause state-dependent shifts in understorey plant communities. Oecologia 173:859-870. http://dx.doi.org/10.1007/s00442-013-2648-1

Kattsov, V. M., and E. Källén. 2005. Future climate change: modelling and scenarios for the Arctic. Pages 99-150 in Arctic Climate Impact Assessment (ACIA). Arctic climate impact assessment: scientific report. Cambridge University Press, Cambridge, UK.

Kauserud, H., L. C. Stige, J. O. Vik, R. H. Økland, K. Høiland, and N. C. Stenseth. 2008. Mushroom fruiting and climate change. Proceedings of the National Academy of Sciences 105:3811-3814. http://dx.doi.org/10.1073/pnas.0709037105

Kellomäki, S., H. Peltola, T. Nuutinen, K. T. Korhonen, and H. Strandman. 2008. Sensitivity of managed boreal forests in Finland to climate change, with implications for adaptive management. Philosophical Transactions of the Royal Society London B 363:2341-2351. http://dx.doi.org/10.1098/rstb.2007.2204

Keskitalo, E. C. H. 2008. Climate change and globalization in the Arctic - an integrated approach to vulnerability assessment. Earthscan, London, UK.

Keskitalo, E. C. H., and A. A. Kulyasova. 2009. Local adaptation to climate change in fishing villages and forest settlements in north-western Russia. Pages 227-244 in S. Nystén-Haarala, editor. Governance of renewable natural resources. Ashgate, Aldershot, UK.

Koca, D., B. Smith, and M. T. Sykes. 2006. Modelling regional climate change effects on potential natural ecosystems in Sweden. Climatic Change 78:381-406. http://dx.doi.org/10.1007/s10584-005-9030-1

Krebs, C. J., R. Boonstra, K. Cowcill, and A. J. Kenney. 2009. Climatic determinants of berry crops in the boreal forest of the southwestern Yukon. Botany 87:401-408. http://dx.doi. org/10.1139/B09-013

Kujala, H., M. B. Araújo, W. Thuiller, and M. Cabeza. 2011. Misleading results from conventional gap analysis-messages from the warming north. Biological Conservation 144:2450-2458. http://dx.doi.org/10.1016/j.biocon.2011.06.023

le Roux, P. C., L. Pellissier, M. S. Wisz, and M. Luoto. 2014. Incorporating dominant species as proxies for biotic interactions strengthens plant community models. Journal of Ecology 102:767-775. http://dx.doi.org/10.1111/1365-2745.12239

Lindenmayer, D. B., and G. E. Likens. 2009. Adaptive monitoring: a new paradigm for long-term research and monitoring. Trends in Ecology and Evolution 24:482-486. http://dx.doi.org/10.1016/j. tree.2009.03.005

Lindenmayer, D. B., G. E. Likens, C. J. Krebs, and R. J. Hobbs. 2010. Improved probability of detection of ecological "surprises." Proceedings of the National Academy of Sciences 107:21957-21962. http://dx.doi.org/10.1073/pnas.1015696107

Lindner, M., M. Maroschek, S. Netherer, A. Kremer, A. Barbati, J. Garcia-Gonzalo, R. Seidl, S. Delzond, P. Corona, M. Kolström,
M. J. Lexer, and M. Marchetti. 2010. Climate change impacts, adaptive capacity, and vulnerability of European forest ecosystems. Forest Ecology and Management 259:698-709. http:// dx.doi.org/10.1016/j.foreco.2009.09.023

Luoto, M., R. K. Heikkinen, and T. R. Carter. 2004. Loss of palsa mires in Europe and biological consequences. Environmental Conservation 31:30-37. http://dx.doi.org/10.1017/S0376892904001018

McLachlan, J. S., J. J. Hellmann, and M. W. Schwartz. 2007. A framework for debate of assisted migration in an era of climate change. Conservation Biology 21:297-302. http://dx.doi. org/10.1111/j.1523-1739.2007.00676.x

Millennium Ecosystem Assessment (MA). 2003. Ecosystems and human well-being: a framework for asessment. Island Press, Washington, D.C., USA.

Millennium Ecosystem Assessment (MA). 2005a. Ecosystems and human well-being: current state and trends. Island Press, Washington, D.C., USA.

Millennium Ecosystem Assessment (MA). 2005b. Ecosystems and human well-being: multiscale assessments. Island Press, Washington, D.C., USA.

Milly, P. C. D., J. Betancourt, M. Falkenmark, R. M. Hirsch, Z. W. Kundzewicz, D. P. Lettenmaier, and R. J. Stouffer. 2008. Stationarity is dead: whither water management? Science 319:573-574. http://dx.doi.org/10.1126/science.1151915

Moen, J. 2008. Climate change: effects on the ecological basis for reindeer husbandry in Sweden. Ambio 37:304-311. http://dx.doi. org/10.1579/0044-7447(2008)37[304:CCEOTE]2.0.CO;2

Moen, J., K. Aune, L. Edenius, and A. Angerbjörn. 2004. Potential effects of climate change on treeline position in the Swedish mountains. Ecology and Society 9(1): 16. [online] URL: http://www.ecologyandsociety.org/vol9/iss1/art16

Moen, J., and P. Fredman. 2007. Effects of climate change on alpine skiing in Sweden. Journal of Sustainable Tourism 15:418-437. http://dx.doi.org/10.2167/jost624.0

Mooney, H., A. Larigauderie, M. Cesario, T. Elmquist, O. HoeghGuldberg, S. Lavorel, G. M. Mace, M. Palmer, R. Scholes, and T. Yahara. 2009. Biodiversity, climate change, and ecosystem services. Current Opinion in Environmental Sustainability 1:46-54. http://dx.doi.org/10.1016/j.cosust.2009.07.006

Moss, R., and A. Watson. 2001. Population cycles in birds of grouse family (Tetranoidae). Advances in Ecological Research 32:53-111. http://dx.doi.org/10.1016/S0065-2504(01)32011-1

Mouillot, D., D. R. Bellwood, C. Baraloto, J. Chave, R. Galzin, M. Harmelin-Vivien, M. Kulbicki, S. Lavergne, S. Lavorel, N. Mouquet, C. E. T. Paine, J. Renaud, and W. Thuiller. 2013. Rare species support vulnerable functions in high-diversity ecosystems. PLoS Biology 11(5):e1001569. http://dx.doi.org/10.1371/journal. pbio. 1001569

Niemelä, P., F. S. Chapin III, K. Danell, and J. P. Bryant. 2001. Herbivory-mediated responses of selected boreal forests to climatic change. Climatic Change 48:427-440. http://dx.doi. org/10.1023/A:1010787714349 
Normand, S., U. A. Treier, C. Randin, P. Vittoz, A. Guisan, and J.-C. Svenning. 2009. Importance of abiotic stress as a range-limit determinant for European plants: insights from species responses to climatic gradients. Global Ecology and Biogeography 18:437-449. http://dx.doi.org/10.1111/j.1466-8238.2009.00451.x

O'Brien, K. L., and R. M. Leichenko. 2000. Double exposure: assessing the impacts of climate change within the context of economic globalization. Global Environmental Change 10:221-232. http://dx.doi.org/10.1016/S0959-3780(00)00021-2

Olofsson, J., L. Ericsson, M. Torp, S. Stark, and R. Baxter. 2011. Carbon balance of Arctic tundra under increased snow cover mediated by a plant pathogen. Nature Climate Change 1:220-223. http://dx.doi.org/10.1038/nclimate1142

Olofsson, J., H. Tømmervik, and T. V. Callaghan. 2012. Vole and lemming activity observed from space. Nature Climate Change 2:880-883. http://dx.doi.org/10.1038/nclimate1537

Overland, J. E., M. Wang, J. E. Walsh, J. H. Christensen, V. M. Kattsov, and W. L. Chapman. 2011. Climate model projections for the Arctic. Chapter 3 in Arctic Monitoring and Assessment Programme (AMAP). Snow, water, ice and permafrost in the Arctic (SWIPA): climate change and the cryosphere. AMAP, Oslo, Norway.

Overpeck, J., J. Cole, and P. J. Bartlein. 2005. A "paleoperspective" on climate variability and change. Pages 91-108 in T. E. Lovejoy and L. J. Hannah, editors. Climate change and biodiversity. Yale University Press, New Haven, Connecticut, USA.

Pellissier, L., K. A. Bråthen, J. Pottier, C. F. Randin, P. Vittoz, A. Dubuis, N. G. Yoccoz, T. Alm, N. E. Zimmermann, and A. Guisan. 2010. Species distribution models reveal apparent competitive and facilitative effects of a dominant species on the distribution of tundra plants. Ecography 33:1004-1014. http://dx. doi.org/10.1111/j.1600-0587.2010.06386.X

Perch-Nielsen, S. L., B. Amelung, and R. Knutti. 2010. Future climate resources for tourism in Europe based on the daily Tourism Climatic Index. Climatic Change 103:363-381. http://dx. doi.org/10.1007/s10584-009-9772-2

Peterson, G. D., T. D. Beard Jr., B. E. Beisner, E. M. Bennett, S. R. Carpenter, G. S. Cumming, C. L. Dent, and T. D. Havlicek. 2003. Assessing future ecosystem services: a case study of the Northern Highlands Lake District, Wisconsin. Conservation Ecology 7(3): 1. [online] URL: http://www.consecol.org/vol7/iss3/ art1/

Plummer, R., and D. Armitage, editors. 2010. Adaptive capacity and environmental governance. Springer, Berlin, Germany.

Post, E., and N. C. Stenseth. 1998. Large-scale climatic fluctuation and population dynamics of moose and white-tailed deer. Journal of Animal Ecology 67:537-543. http://dx.doi.org/10.1046/ j.1365-2656.1998.00216.x

Pressey, R. L., M. Cabeza, M. E. Watts, R. M. Cowling, and K. A. Wilson. 2007. Conservation planning in a changing world. Trends in Ecology and Evolution 22:583-592. http://dx.doi. org/10.1016/j.tree.2007.10.001

Ragner, C. L. 2008. The Northern Sea route. Pages 114-127 in T. Hallberg, editor. The Barents - a Nordic borderland. Arena Norden, Stockholm, Sweden.
Ravolainen, V., K. A. Bråthen, R. A. Ims, N. G. Yoccoz, J.-A. Henden, and S. T. Killengreen. 2011. Rapid, landscape scale responses in riparian tundra vegetation to exclusion of small and large mammalian herbivores. Basic and Applied Ecology 12:643-653. http://dx.doi.org/10.1016/j.baae.2011.09.009

Ravolainen, V., K. A. Bråthen, N. Yoccoz, J. K. Nguyen, and R. A. Ims. 2014. Complementary impacts of small rodents and semidomesticated ungulates limit tall shrub expansion in the tundra. Journal of Applied Ecology 51:234-241. http://dx.doi. org/10.1111/1365-2664.12180

Rees, W. G., F. M. Stammler, F. S. Danks, and P. Vitebsky. 2008. Vulnerability of European reindeer husbandry to global change. Climatic Change 87:199-217. http://dx.doi.org/10.1007/s10584-007-9345-1

Reist, J. D., F. J. Wrona, T. D. Prowse, M. Power, J. B. Dempson, R. J. Beamish, J. R. King, T. J. Carmichael, and C. D. Sawatzky. 2006. General effects of climate change on Arctic fishes and fish populations. Ambio 35:370-380. http://dx.doi.org/10.1579/0044-7447 (2006)35[370:GEOCCO]2.0.CO;2

Ricciardi, A., and D. Simberloff. 2009. Assisted colonization is not a viable conservation strategy. Trends in Ecology and Evolution 24:248-253. http://dx.doi.org/10.1016/j.tree.2008.12.006

Rummukainen, M., S. Bergström, G. Persson, J. Rodhe, and M. Tjernström. 2004. The Swedish Regional Climate Modelling Programme, SWECLIM: a review. Ambio 33:176-182. http://dx. doi.org/10.1579/0044-7447-33.4.176

Sætersdal, M., H. J. B. Birks, and S. Peglar. 1998. Predicting changes in Fennoscandian vascular-plant species richness as a result of future climatic change. Journal of Biogeography 25:111-112. http://dx.doi.org/10.1046/j.1365-2699.1998.251192. $\underline{x}$

Sandström, C., J. Moen, C. Widmark, and Ö. Danell. 2006. Progressing toward co-management through collaborative learning: forestry and reindeer husbandry in dialogue. International Journal of Biodiversity Science and Management 2:326-333. http://dx.doi.org/10.1080/17451590609618153

Schmidt, N. M., R. A. Ims, T. T. Høye, O. Gilg, L. H. Hansen, J. Hansen, M. Lund, E. Fuglei, M. C. Forchhammer, and B. Sittler. 2012. Response of an arctic predator guild to collapsing lemming cycles. Proceedings of the Royal Society B Biological Sciences 279:4417-4422. http://dx.doi.org/10.1098/rspb.2012.1490

Schmitz, O. J., E. Post, C. E. Burns, and K. M. Johnston. 2003. Ecosystem responses to global climate change: moving beyond color mapping. BioScience 53:1199-1205. http://dx.doi. org/10.1641/0006-3568(2003)053[1199:ERTGCC]2.0.CO;2

Schmölcke, U., and F. E. Zachos. 2005. Holocene distribution and extinction of the moose (Alces alces, Cervidae) in Central Europe. Mammalian Biology 70:329-344. http://dx.doi.org/10.1016/j. mambio.2005.08.001

Schröter, D., W. Cramer, R. Leemans, I. C. Prentice, M. B. Araújo, N. W. Arnell, A. Bondeau, H. Bugmann, T. R. Carter, C. A Gracia, A. C. de la Vega-Leinert, M. Erhard, F. Ewert, M. Glendining, J. I. House, S. Kankaanpää, R. J. T. Klein, S. Lavorel, M. Lindner, M. J. Metzger, J. Meyer, T. D. Mitchell, I. Reginster, M. Rounsevell, S. Sabaté, S. Sitch, B. Smith, J. Smith, P. Smith, 
M. T. Sykes, K. Thonicke, W. Thuiller, G. Tuck, S. Zaehle, and B. Zierl. 2005. Ecosystem service supply and vulnerability to global change in Europe. Science 310:1333-1337. http://dx.doi. org/10.1126/science.1115233

Selås, V. 2000. Seed production of a masting dwarf shrub, Vaccinium myrtillus, in relation to previous reproduction and weather. Canadian Journal of Botany 78:423-429. http://dx.doi. org/10.1139/b00-017

Serreze, M. C., J. E. Walsh, F. S. Chapin III, T. Osterkamp, M. Dyurgerov, V. Romanovsky, W. C. Oechel, J. Morison, T. Zhang, and R. G. Barry. 2000. Observational evidence of recent change in the northern high-latitude environment. Climatic Change 46:159-207. http://dx.doi.org/10.1023/A:1005504031923

Solberg, B., A. Moiseyev, and A. M. I. Kallio. 2003. Economic impacts of accelerating forest growth in Europe. Forest Policy and Economics 5:157-171. http://dx.doi.org/10.1016/S1389-9341(03) $\underline{00022-4}$

Sténs, A., and C. Sandström. 2013. Divergent interests and ideas around property rights: the case of berry harvesting in Sweden. Forest Policy and Economics 33:56-62. http://dx.doi.org/10.1016/ j.forpol.2012.05.004

Stien, A., R. A. Ims, S. D. Albon, E. Fuglei, R. J. Irvine, E. Ropstad, O. Halvorsen, R. Langvatn, L.-E. Loe, V. Veiberg, and N. G. Yoccoz. 2012. Congruent responses to weather variability in high-arctic herbivores. Biology Letters 8:1002-1005. http://dx. doi.org/10.1098/rsbl.2012.0764

Sutinen, R., E. Hyvönen, A. Ruther, A. Ahl, and M.-L. Sutinen. 2005. Soil-driven timberline of spruce (Picea abies) in Tanaelv Belt-Lapland Granulite Transition, Finland. Arctic, Antarctic, and Alpine Research 37:611-619. http://dx.doi.org/10.1657/1523-0430 (2005)037[0611:STOSPA]2.0.CO;2

Svenning, J.-C., and B. Sandel. 2013. Disequilibrium vegetation dynamics under future climate change. American Journal of Botany 100:1266-1286. http://dx.doi.org/10.3732/ajb.1200469

Svenning, J.-C., and F. Skov. 2004. Limited filling of the potential range in European tree species. Ecology Letters 7:565-573. http:// dx.doi.org/10.1111/j.1461-0248.2004.00614.x

Sykes, M. T. 2001. Modelling the potential distribution and community dynamics of lodgepole pine (Pinus contorta Dougl. ex. Loud.) in Scandinavia. Forest Ecology and Management 141:69-84. http://dx.doi.org/10.1016/S0378-1127(00)00490-4

Thuiller, W., S. Lavorel, M. B. Araújo, M. T. Sykes, and I. C. Prentice. 2005. Climate change threats to plant diversity in Europe. Proceedings of the National Academy of Sciences 102:8245-8250. http://dx.doi.org/10.1073/pnas.0409902102

Trømborg, E., T. F. Bolkesjø, and B. Solberg. 2008. Biomass market and trade in Norway: status and future prospects. Biomass and Bioenergy 32:660-671. http://dx.doi.org/10.1016/j.

biombioe.2008.02.022

Tveraa, T., P. Fauchald, N. G. Yoccoz, R. A. Ims, R. Aanes, and K. A. Høgda. 2007. What regulate and limit reindeer populations in Norway? Oikos 116:706-715. http://dx.doi.org/10.1111/ j.0030-1299.2007.15257.x
Tyler, N. J. C., J. M. Turi, M. A. Sundset, K. S. Bull, M. N. Sara, E. Reinert, N. Oskal, C. Nellemann, J. J. McCarthy, S. D. Mathiesen, M. L. Martello, O. H. Magga, G. K. Hovelsrud, I. Hanssen-Bauer, N. I. Eira, I. M. G. Eira, and R. W. Corell. 2007. Saami reindeer pastoralism under climate change: applying a generalized framework for vulnerability studies to a sub-arctic social-ecological system. Global Environmental Change 17:191-206. http://dx.doi.org/10.1016/j.gloenvcha.2006.06.001

Ulvevadet, B., and V. H. Hausner. 2011. Incentives and regulations to reconcile conservation and development: thirty years of governance of the Sami pastoral ecosystem in Finnmark, Norway. Journal of Environmental Management 92:2794-2802. http://dx.doi.org/10.1016/j.jenvman.2011.06.026

Valtonen, A., M. P. Ayres, H. Roininen, J. Pöyry, and R. Leinonen. 2011. Environmental controls on the phenology of moths: predicting plasticity and constraint under climate change. Oecologia 165:237-248. http://dx.doi.org/10.1007/s00442-010-1789-8

Vlasova, T., and S. Volkov. 2013. Methodology of sociallyoriented observations and the possibilities of their implementation in the Arctic resilience assessment. Polar Record 49:248-253. http://dx.doi.org/10.1017/S0032247413000119

Vlassova, T. K. 2006. Arctic residents' observations and human impact assessments in understanding environmental changes in boreal forests: Russian experience and circumpolar perspectives. Mitigation and Adaptation Strategies for Global Change 11:897-909. http://dx.doi.org/10.1007/s11027-005-9023-4

Vucetich, J. A., and R. O. Peterson. 2004. The influence of prey consumption and demographic stochasticity on population growth rate of Isle Royale wolves Canis lupus. Oikos 107:309-320. http://dx.doi.org/10.1111/j.0030-1299.2004.13483.x

Watson, A., R. Moss, and S. Rae. 1998. Population dynamics of Scottish rock ptarmigan cycles. Ecology 79:1174-1192. http://dx. doi.org/10.1890/0012-9658(1998)079[1174:PDOSRP]2.0.CO;2

Watson, A., R. Moss, and P. Rothery. 2000. Weather and synchrony in 10-year population cycles of Rock Ptarmigan and Red Grouse in Scotland. Ecology 81:2126-2136. http://dx.doi. org/10.1890/0012-9658(2000)081[2126:WASIYP]2.0.CO;2

Weber, C., C. Nilsson, L. Lind, K. T. Alfredsen, and L. E. Polvi. 2013. Winter disturbances and riverine fish in temperate and cold regions. BioScience 63:199-210. http://dx.doi.org/10.1525/ bio.2013.63.3.8

Wilkie, M. P., K. Davidson, M. A. Brobbel, J. D. Kieffer, R. K. Booth, A. T. Bielak, and B. L. Tufts. 1996. Physiology and survival of wild Atlantic salmon following angling in warm summer waters. Transactions of the American Fisheries Society 125:572-580. http://dx.doi.org/10.1577/1548-8659(1996)125<0572: PASOWA $>2.3 . \mathrm{CO} ; 2$

Williams, P., L. Hannah, S. Andelman, G. Midgley, M. Araújo, G. Hughes, L. Manne, E. Martinez-Meyer, and R. Pearson. 2005. Planning for climate change: identifying minimum-dispersal corridors for the Cape Proteaceae. Conservation Biology 19:1063-1074. http://dx.doi.org/10.1111/j.1523-1739.2005.00080. $\underline{x}$ 
Wolf, A., T. V. Callaghan, and K. Larson. 2008a. Future changes in vegetation and ecosystem function of the Barents Region. Climatic Change 87:51-73. http://dx.doi.org/10.1007/s10584-007-9342-4

Wolf, A., M. V. Kozlov, and T. V. Callaghan. 2008b. Impact of non-outbreak insect damage on vegetation in northern Europe will be greater than expected during a changing climate. Climatic Change 87:91-106. http://dx.doi.org/10.1007/s10584-007-9340-6

Woo, M. K., R. Thorne, K. Szeto, and D. Q. Yang. 2008. Streamflow hydrology in the boreal region under the influences of climate and human interference. Philosophical Transactions of the Royal Society London B 363:2251-2260. http://dx.doi. org/10.1098/rstb.2007.2197

Wookey, P. A., R. Aerts, R. D. Bardgett, F. Baptist, K. A. Bråthen, J. H. C. Cornelissen, L. Gough, I. P. Hartley, D. W. Hopkins, S. Lavorel, and G. R. Shaver. 2009. Ecosystem feedbacks and cascade processes: understanding their role in the responses of Arctic and alpine ecosystems to environmental change. Global Change Biology 15:1153-1172. http://dx.doi.org/10.1111/

j.1365-2486.2008.01801.x

Wrona, F. J., T. D. Prowse, J. D. Reist, R. Beamish, J. J. Gibson, J. Hobbie, E. Jeppesen, J. King, G. Koeck, A. Korhola, L. Lévesque, R. Macdonald, M. Power, V. Skvortsov, and W. Vincent. 2005. Freshwater ecosystems and fisheries. Pages 353-452 in Arctic Climate Impact Assessment (ACIA). Arctic climate impact assessment: scientific report. Cambridge University Press, Cambridge, UK.

Yaroshenko, A. Y., P. V. Potapov, and S. A. Turubanova. 2001. The last intact forest landscapes of northern European Russia. Greenpeace Russia and Global Forest Watch, Moscow, Russia. 